\title{
Review \\ Recent Advances in the Genetic of MALT Lymphomas
}

\author{
Juan José Rodríguez-Sevilla ${ }^{1,2}$ and Antonio Salar ${ }^{1,2,3, *(1)}$ \\ 1 Department of Hematology, Hospital del Mar-IMIM, 08003 Barcelona, Spain; 63639@parcdesalutmar.cat \\ 2 Group of Applied Clinical Research in Hematology, Cancer Research Program-IMIM (Hospital del Mar \\ Medical Research Institute), 08003 Barcelona, Spain \\ 3 Life and Health Sciences Department, Pompeu Fabra University, 08003 Barcelona, Spain \\ * Correspondence: asalar@parcdesalutmar.cat; Tel.: +34-93-248-3341
}

\section{check for}

updates

Citation: Rodríguez-Sevilla, J.J.; Salar, A. Recent Advances in the Genetic of MALT Lymphomas. Cancers 2022, 14, 176. https://doi.org/10.3390/ cancers14010176

Academic Editor: Francesco Bertoni

Received: 28 November 2021

Accepted: 29 December 2021

Published: 30 December 2021

Publisher's Note: MDPI stays neutral with regard to jurisdictional claims in published maps and institutional affiliations.

Copyright: (C) 2021 by the authors. Licensee MDPI, Basel, Switzerland This article is an open access article distributed under the terms and conditions of the Creative Commons Attribution (CC BY) license (https:// creativecommons.org/licenses/by/ $4.0 /)$.
Simple Summary: Mucosa-associated lymphoid tissue (MALT) lymphoma is the most common subtype of marginal zone lymphomas. These B-cell neoplasms may arise from many organs and usually have an indolent behavior. Recurrent chromosomal translocations and cytogenetic alterations are well characterized, some of them being associated to specific sites. Through next-generation sequencing technologies, the mutational landscape of MALT lymphomas has been explored and available data to date show that there are considerable variations in the incidence and spectrum of mutations among MALT lymphoma of different sites. Interestingly, most of these mutations affect several common pathways and some of them are potentially targetable. Gene expression profile and epigenetic studies have also added new information, potentially useful for diagnosis and treatment. This article provides a comprehensive review of the genetic landscape in MALT lymphomas.

\begin{abstract}
Mucosa-associated lymphoid tissue (MALT) lymphomas are a diverse group of lymphoid neoplasms with B-cell origin, occurring in adult patients and usually having an indolent clinical behavior. These lymphomas may arise in different anatomic locations, sharing many clinicopathological characteristics, but also having substantial variances in the aetiology and genetic alterations. Chromosomal translocations are recurrent in MALT lymphomas with different prevalence among different sites, being the 4 most common: $\mathrm{t}(11 ; 18)(\mathrm{q} 21 ; \mathrm{q} 21), \mathrm{t}(1 ; 14)(\mathrm{p} 22 ; \mathrm{q} 32), \mathrm{t}(14 ; 18)(\mathrm{q} 32 ; \mathrm{q} 21)$, and $\mathrm{t}(3 ; 14)(\mathrm{p} 14.1 ; \mathrm{q} 32)$. Several chromosomal numerical abnormalities have also been described, but probably represent secondary genetic events. The mutational landscape of MALT lymphomas is wide, and the most frequent mutations are: TNFAIP3, CREBBP, KMT2C, TET2, SPEN, KMT2D, LRP1B, PRDM1, EP300, TNFRSF14, NOTCH1/NOTCH2, and B2M, but many other genes may be involved. Similar to chromosomal translocations, certain mutations are enriched in specific lymphoma types. In the same line, variation in immunoglobulin gene usage is recognized among MALT lymphoma of different anatomic locations. In the last decade, several studies have analyzed the role of microRNA, transcriptomics and epigenetic alterations, further improving our knowledge about the pathogenic mechanisms in MALT lymphoma development. All these advances open the possibility of targeted directed treatment and push forward the concept of precision medicine in MALT lymphomas.
\end{abstract}

Keywords: MALT lymphoma; marginal zone; Helicobacter pylori; extranodal lymphoma; gastric lymphoma

\section{Introduction}

Mucosa-associated lymphoid tissue (MALT) lymphoma was first described in 1983 by Isaacson and Wright in the stomach but may arise from other mucosal tissues [1]. According to the WHO classification [2], MALT lymphomas are one of the three recognized subtypes of marginal zone lymphomas (MZL), a group of indolent lymphoid neoplasms which represents 7\% of all mature non-Hodgkin lymphomas (NHL) [3]. Based on data from SEER18 program, MALT lymphomas represent $60.8 \%$ of MZLs, followed by nodal MZL (NMZL) (30.3\%) and splenic MZL (SMZL) (8.9\%) [4]. According to this program, the incidence of 
MALT lymphomas in the US from 2001-2017 has increased $+1.1 \%$ per year [4], despite the decrease in the incidence of gastric MALT lymphomas associated with Helicobacter pylori (H. pylori) recently described in several studies [5].

MALT lymphomas mainly occur in adults, with a median age about 60 years. Men and women are affected equally, although there is site specific female predominance in the parotid gland and breast [6]. MALT lymphomas can occur at any extranodal site. In health, these tissues are usually almost devoid of lymphoid tissue; however, they accumulate B lymphocytes in response to persistent antigenic stimulation due to chronic infections or autoimmune disorders $[7,8]$. The most common anatomic sites are the stomach $(30 \%)$, followed by eye/adnexa (12\%), skin (10\%), lung $(9 \%)$ and salivary gland $(7 \%)$ [4]. However, these lymphomas have been described at many other mucosal organs, such as thyroid, liver, small intestine, large intestine, bladder, dura, and many other sites [7,9].

Gastric MALT lymphoma is linked with chronic H. pylori infection, satisfying Koch's postulates for an etiologic agent [10]. Albeit not with the same clear evidence, other infectious agents have been associated with MALT lymphomas: Helicobacter heilmannii in the stomach [11], Chlamydia psittaci (C. psittaci) in the ocular adnexa [12,13], Borrelia burgdorferi in the skin [14,15], Campylobacter jejuni in immunoproliferative small intestine disease [16] and, Achromobacter xylosoxidans in the lung [17]. Autoimmune conditions have been further associated with MALT lymphoma, including Sjogren's disease, lymphoepithelial sialadenitis and Hashimoto's thyroiditis [18]. There are also promising leads related to other infections (hepatitis B and C viruses and human immunodeficiency virus), other B-cell activating autoimmune conditions (systemic lupus erythematosus), trichloroethylene exposure, certain occupations, hair dye, recreational sun exposure, smoking, and alcohol use, but these require further research [4].

MALT lymphomas are considered indolent neoplasms with 5-year relative survival rate of $93.8 \%$, higher than that observed in SMZL (85.3\%) and NMZL (82.8\%) [4]. Among MALT lymphoma sites, 5-year survival is highest for skin (100\%) and lowest for small intestine $(87.9 \%)$. However, occasionally, MALT lymphomas can progress and transform into aggressive high-grade (diffuse large B cell lymphoma (DLBCL)) and in those cases the survival rate drops sharply.

High throughput genome-wide methodologies, the complete sequencing of the human genome and recent developments in next generation sequencing (NGS) have allowed for unprecedented insights into the genomic alterations that underlie oncogenesis, tumor biology, and survival. Since more than $95 \%$ of patients with hematologic malignancies have adequate tissue for genomic profiling, this represents an excellent opportunity to improve diagnosis and classification, to look for prognostic markers and also for detection of pharmacologically tractable targets [19]. This review will summarize the latest advances in the genetics and molecular insights of MALT lymphomas.

\section{IGHV Usage}

A functional B-cell receptor (BCR) is essential for the biology of B-cells. MALT lymphoma cells almost always express surface immunoglobulin (Ig) M and its BCR signalling is functional. This is supported by their proliferative responses to mitogens [20] and the responses achieved with treatment with Bruton Tyrosine Kinase (BTK) inhibitors [21].

MALT lymphomas have highly altered variable heavy chain immunoglobulin (IGHV) and variable light chain immunoglobulin (IGLV) genes, which are consistent with germinal center (GC) or post-GC origin [22-24]. A role for antigen-driven clonal expansion of the lymphoma cells is shown through the evidence of ongoing somatic hypermutation in the IGHV [25]. The involvement of antigens is also supported by evidence of clonal evolution within the tumor, suggesting selective pressure to increase affinity of the Ig for antigens [26-28]. Despite large mutation loads, the overall structure of the Ig is typically retained in these lymphomas [25].

The variation in Ig gene usage among MALT lymphoma of different anatomic locations is presumably the result of adaptive response and clonal selection induced by their varied 
aetiologies, resulting in different antigen exposures [29]. The Ig from MALT lymphoma of various anatomic sites is autoreactive rather than recognizing antigens from infectious agents. The auto-reactivity may range from polyreactive to various self-antigens to a highaffinity binding to IgG-Fc, a characteristic of rheumatoid factors (RF) [25,30]. In fact, many of these MALT lymphoma derived immunoglobulins share the fundamental features of known autoantibodies [31].

In MALT lymphomas of the salivary gland (SGMZL), there is a clear skewed usage of IGHV1-69/J4 (55\%) or IGHV3-7/J3 (15\%) rearrangements, and this together with other less frequent (IGHV4-59/J2(J5) and IGHV3-30/JH4) rearrangements indicates that most salivary gland MALT lymphomas express BCR that potentially bears RF activities [32,33].

IGHV4-34 (18\%) is the most often usage in ocular adnexal MALT lymphoma (OAMZL), followed by IGHV3-23 (12-17\%), IGHV3-30 (10-14\%), and IGHV3-7 (9\%) [34-39]. OAMZL carry no or very rare mutation at the conserved VH FR1 Q6W7A24V25Y26 residues, and in contrast, IGVH4-34 mutations are common at the CDR2 N-link glycosylation site and FR3 K90L91S92 residues [40]. In addition, IGHV gene usage in OAMZL is biased by the presence of $C$. psittaci infection. C. psittaci-negative cases have a much greater prevalence of IGHV4-34 usage than those C. psittaci-positive [41], raising the possibility that other yet unknown pathogens may be involved in their pathogenesis, boosting the formation of an inflammatory environment in which autoantigen exposure could promote the malignant proliferation of autoreactive cells. Moreover, TNFAIP3 inactivation by deletion or mutation was significantly higher in MALT lymphomas with IGHV4-34 rearrangement (54\%), particularly in those of OAMZL (70\%), than in those using other IGHV genes (20\%). The concurrence of IGHV4-34 rearrangement and TNFAIP3 inactivation points toward a cooperative relationship of between these two events in OAMZL lymphomagenesis [37].

MALT lymphomas from other sites have also biased usage of IG genes, albeit those coding for autoantibodies are still overrepresented. Gastric MALT lymphomas (GMZL) have a biased use of IGHV4-34, IGHV3-7 and IGHV1-69 genes [25,30,37,42-46] and those responsive to $H$. pylori antibiotic treatment and without the $t(11 ; 18)(q 21 ; q 21)$ of IGHV3-30 or IGHV3-23. MALT lymphomas of the lung and skin have also found to have biased usage of IGHV3 or IGHV4 and IGHVH1-69 or IGHVH4-59, respectively [47]. Moreover, the usage of IGHV4-34 and IGHV1-69 in MALT lymphoma is frequently associated with a biased usage of IGLV (IGKV3-20), suggesting recognition of certain antigenic determinants [25,48]. However, the prognostic impact of both the biased usage of Ig genes or their mutational status (unmutated vs. mutated) remains to be determined in MALT lymphomas.

\section{Cytogenetics}

The identification of cytogenetic abnormalities constitutes an important tool for establishing the diagnosis, monitoring the clinical course, and assessing the prognosis of patients with B-cell lymphomas. Cytogenetic analysis in MALT lymphomas was initially hampered by the facts that biopsies are usually small (most taken by endoscopic procedures) and then rarely subjected to conventional cytogenetic analysis and also, because its proliferation in vitro is often poor. Then, during several years, data were limited in comparison with other types of indolent B-cell lymphomas. However, the application of FISH (fluorescence in-situ hybridization), SKY (spectral karyotyping) and high-resolution technologies such as array based comparative genomic hybridization (array-CGH) have improved our knowledge of chromosomal abnormalities in MALT lymphomas.

In the last two decades, a variety of chromosomal structural and numerical alterations have been described in MALT lymphomas (Table 1). Chromosomal translocations are recurrent in MALT lymphomas, but not in NMZL or SMZL, and their prevalence differs according to disease sites $[49,50]$. Many translocations have been reported in MALT lymphomas, but the 4 most common are $\mathrm{t}(1 ; 14)(\mathrm{p} 22 ; \mathrm{q} 32), \mathrm{t}(11 ; 18)(\mathrm{q} 21 ; \mathrm{q} 21), \mathrm{t}(14 ; 18)(\mathrm{q} 32 ; \mathrm{q} 21)$, and $t(3 ; 14)(p 14.1 ; q 32)$. All these translocations and their products target the activation of nuclear factor k-light-chain-enhancer of activated B-cells (NF-kB) pathway [51-53]. 
Table 1. Most common genetic aberrations detected in MALT lymphomas at different sites.

\begin{tabular}{|c|c|c|c|c|c|c|}
\hline Location & $\begin{array}{c}\text { Antigen } \\
\text { Exposure } \\
\text { Association }\end{array}$ & IGHV Usage & Abnormality & Involved Genes & $\begin{array}{l}\text { Copy Number } \\
\text { Variations }\end{array}$ & $\begin{array}{c}\text { Other } \\
\text { Imbalances }\end{array}$ \\
\hline GASTRIC & $\begin{array}{c}\text { Helicobacter pylori } \\
\text { Helicobacter } \\
\text { heilmannii } \\
\text { Campylobacter } \\
\text { jejuni (small } \\
\text { intestine) }\end{array}$ & $\begin{array}{l}\text { IGHV4-34 } \\
\text { IGHV3-7 } \\
\text { IGHV1-69 } \\
\text { IGHV1-2 } \\
\text { IGHV3-23 }\end{array}$ & $\begin{array}{c}\mathrm{t}(11 ; 18)(\mathrm{q} 21 ; \mathrm{q} 21) \\
20-25 \% \text { (intestinal } \\
33 \%) \\
\mathrm{t}(1 ; 14)(\mathrm{p} 22 ; \mathrm{q} 32) 4 \%\end{array}$ & $\begin{array}{l}\text { BIRC3-MALT1 } \\
\text { IGHV-BCL10 }\end{array}$ & $\begin{array}{l}\text { Trisomy } 3 \\
\text { Trisomy } 18\end{array}$ & $\begin{array}{l}\text { TNFAIP3 } \\
\text { deletion }\end{array}$ \\
\hline $\begin{array}{l}\text { OCULAR } \\
\text { ADNEXA }\end{array}$ & Chlamydia psittaci & $\begin{array}{l}\text { IGHV4-34: } 18 \% \\
\text { IGHV3-23: 12-17\% } \\
\text { IGHV3-30: 10-14\% } \\
\text { IGHV3-7: } 9 \%\end{array}$ & $\begin{array}{l}\mathrm{t}(11 ; 18)(\mathrm{q} 21 ; \mathrm{q} 21) 10 \% \\
\mathrm{t}(14 ; 18)(\mathrm{q} 32 ; \mathrm{q} 21) 7 \% \\
\mathrm{t}(3 ; 14)(\mathrm{p} 14.1 ; \mathrm{q} 32)\end{array}$ & $\begin{array}{l}\text { BIRC3-MALT1 } \\
\text { IGHV-MALT1 } \\
\text { IGHV-FOXP1 }\end{array}$ & $\begin{array}{l}\text { Trisomy } 18 \\
6 \mathrm{q} \text { gain } 30 \% \\
\text { 3q gain } \\
\text { 18q gain }\end{array}$ & $\begin{array}{c}\text { TNFAIP3 } \\
\text { deletion } 19 \%\end{array}$ \\
\hline THRYOID & $\begin{array}{l}\text { Hashimoto } \\
\text { thyroiditis }\end{array}$ & IGHV3-30 & $\begin{array}{c}\mathrm{t}(3 ; 14)(\mathrm{p} 14.1 ; \mathrm{q} 32) \\
7-56 \% \\
\mathrm{t}(14 ; 18)(\mathrm{q} 32 ; \mathrm{q} 21)\end{array}$ & $\begin{array}{l}\text { IGHV-FOXP1 } \\
\text { IGHV-MALT1 }\end{array}$ & Trisomy 3 & $\begin{array}{c}\text { TNFAIP3 } \\
\text { deletion } 11 \% \\
\text { PD-L1 deletion } \\
53 \%\end{array}$ \\
\hline $\begin{array}{l}\text { SALIVAL } \\
\text { GLAND }\end{array}$ & $\begin{array}{l}\text { Lymphoepithelial } \\
\text { sialadenitis } \\
\text { Sjögren syndrome }\end{array}$ & $\begin{array}{l}\text { IGHV1-69/J4: 55\% } \\
\text { IGHV3-7/J3 15\% } \\
\text { IGHV4-59/J2(J5) } \\
\text { IGHV3-30/JH4 }\end{array}$ & $\mathrm{t}(\mathrm{X} ; 14)(\mathrm{p} 11.4 ; \mathrm{q} 32)$ & IGHV-GPR34 & & $\begin{array}{c}\text { TNFAIP3 } \\
\text { deletion } 8 \%\end{array}$ \\
\hline SKIN & Borrelia burgdorferi & $\begin{array}{l}\text { IGHV1-69 } \\
\text { IGHV4-59 } \\
\text { IGHV3-30 }\end{array}$ & $\begin{array}{l}\mathrm{t}(14 ; 18)(\mathrm{q} 32 ; \mathrm{q} 21) 10 \% \\
\mathrm{t}(3 ; 14)(\mathrm{p} 14.1 ; \mathrm{q} 32)\end{array}$ & IGHV-MALT1 & & \\
\hline LUNG & $\begin{array}{c}\text { Achromobacter } \\
\text { xylosoxidans }\end{array}$ & $\begin{array}{c}\text { IGHV3 } \\
\text { IGHV4-34 }\end{array}$ & $\begin{array}{c}\mathrm{t}(11 ; 18)(\mathrm{q} 21 ; \mathrm{q} 21) 40 \% \\
\mathrm{t}(11 ; 12 ; 18)(\mathrm{q} 21 ; \mathrm{q} 13 ; \mathrm{q} 21) \\
\mathrm{t}(11 ; 14 ; 18)(\mathrm{q} 21 ; \mathrm{q} 32 ; \mathrm{q} 21) \\
\mathrm{t}(1 ; 14)(\mathrm{p} 22 ; \mathrm{q} 32) 9 \% \\
\mathrm{t}(14 ; 18)(\mathrm{q} 32 ; \mathrm{q} 21) 6-9 \%\end{array}$ & $\begin{array}{l}\text { IGHV-BCL10 } \\
\text { IGHV-MALT1 }\end{array}$ & $\begin{array}{l}\text { 3q gain } \\
18 q \text { gain }\end{array}$ & \\
\hline
\end{tabular}

The most common recurrent translocation is $\mathrm{t}(11 ; 18)(\mathrm{q} 21 ; \mathrm{q} 21)$ which juxtaposes the $\mathrm{N}$-terminal region API2 gene, containing 3 BIR domains with inhibitor caspase activity, and the C-terminal region of MALT1 gene, containing an intact caspase p20-like domain [54-59]. The resulting fusion product undergo oligomerization, generating a chimeric protein that induces aberrant nuclear expression of BCL-10 and activation of both canonical and noncanonical NF-KB pathways, promoting cell survival and proliferation [55,60-64]. A recent molecular mechanism described for the API2/MALT1 fusion protein shows that the tumor suppressor gene LIMA1 binds BIRC2 and is proteolytically cleaved by MALT1 through its paracaspase activity. This cleavage originates a LIM domain-only-containing fragment with oncogenic properties in vitro and in vivo [65].

$\mathrm{t}(11 ; 18)(\mathrm{q} 21 ; \mathrm{q} 21)$ is most frequent in MALT lymphomas of the lung $(40 \%)$ and stomach $(20-25 \%)$. This translocation is also found in the intestinal (33\%; with different frequencies between primary $(12.5 \%)$ and secondary forms $(57 \%)$, but rare in colorectal cases), the ocular adnexa $(10 \%)$, and it is uncommon or not present in MALT lymphomas of the thyroid, salivary gland, and skin $[49,50,56,59,63,66-72]$. Aneuploidy is rarely observed. Variant translocations of the $\mathrm{t}(11 ; 18)(\mathrm{q} 21 ; \mathrm{q} 21)$ have been described, the three-way translocation $\mathrm{t}(11 ; 12 ; 18)(\mathrm{q} 21 ; \mathrm{q} 13 ; \mathrm{q} 21)$ in the lung $[73,74], \mathrm{t}(6 ; 18 ; 11)(\mathrm{q} 24 ; \mathrm{q} 21 ; \mathrm{q} 21)$ in the stomach [75] and $\mathrm{t}(11 ; 14 ; 18)(\mathrm{q} 21 ; \mathrm{q} 32 ; \mathrm{q} 21)$ in the lung [75].

In the MALT lymphomas of the stomach, $\mathrm{t}(11 ; 18)(\mathrm{q} 21 ; \mathrm{q} 21)$ is found in $47 \%$ and $68 \%$ of cases with stage IE and stage IIE or above, respectively, which do not respond to H. pylori antibiotic treatment, but only in 3\% of those that respond to $H$. pylori eradication [76-87]. Additionally, these $\mathrm{t}(11 ; 18)(\mathrm{q} 21 ; \mathrm{q} 21)$ positive cases often show residual disease and have a higher risk of lymphoma relapse after antibiotic treatment [86,88]. Additionally, patients carrying this translocation do also present a poor response to alkylating agents such as cyclophosphamide or chlorambucil [89]. However, treatment with rituximab is active in monotherapy [90] or in combination with chlorambucil [91] or bendamustine [92]. For 
these reasons, testing for $\mathrm{t}(11 ; 18)(\mathrm{q} 21 ; \mathrm{q} 21)$ at diagnosis is commonly recommended to guide treatment choice $[93,94]$.

Patients with $\mathrm{t}(11 ; 18)$ had more frequent monoclonal gammopathy, in particular of IgM subtype $(31 \% \mathrm{v} 8 \%)$, some of which developed class switch [86,95]. The link between high IgM and $t(11 ; 18)$ could have come via the CD40 pathway, which induces IgM secretion in B cells [96-98]. Finally, this translocation is rarely seen in transformed MALT lymphomas [99].

The $\mathrm{t}(14 ; 18)(\mathrm{q} 32 ; \mathrm{q} 21)$ is the second most common among all balanced translocations in MALT lymphoma and brings the MALT1 gene under the transcriptional control of the $\operatorname{IgG}$ enhancer, then MALT1 expression is deregulated fostering NF-kB activation [67,71,100-103]. MALT1 activation also produces its protease activities, causing specific cleavage and inactivation of NF- $\mathrm{KB}$ negative regulators including TNFAIP3 and CYLD, thus further enhancing NF- $\mathrm{kB}$ activation [104-107]. In addition, the lymphoma cells carrying IGH/MALT1 show not only over-expression of MALT1, but also BCL10 accumulation in cytoplasm. This finding suggests that MALT1 may immobilize BCL10 in cytoplasm through their interaction [102]. Over-expression of MALT1, and also of BCL10, may promote the activation of non-canonical NF- $\mathrm{kB}$ pathway via up-regulation of BAFF expression [108]. This rearrangement is seen in 5-20\% of MALT lymphomas, especially in the liver $(17 \%)$, skin $(10 \%)$, lung (6-9\%) and ocular adnexa (7\%) $[50,67,100,102,109,110]$. Other described sites are the salivary gland, dura and kidney among others [111-113]. This translocation is also described in rare cases of diffuse large B-cell lymphoma [114,115].

The $t(1 ; 14)(p 22 ; q 32)$ juxtaposes the BCL10 gene under the regulatory control of the IGH gene, resulting in deregulated expression [116]. In normal conditions, BCL10 links BCR signalling to the canonical NF-kB pathway, being expressed in the cytoplasm of reactive B-cells [117]. However, BCL10 is aberrantly expressed in the nuclei of lymphoma cells with $\mathrm{t}(1 ; 14)$ (p22;q32)/BCL10-IGH. Over-expression of BCL10 and formation of CBM signalosome via oligomers uniting the CARD domain results in NF- $\mathrm{KB}$ activation [81].

$\mathrm{t}(1 ; 14)$ (p22;q32) is particularly associated with MALT lymphomas, albeit it is infrequent (1-2\% of MALT lymphomas). This translocation may be seen in MALT lymphoma of the lung $(9 \%)$ and stomach (4\%), but it is rare in other sites: ocular adnexa, salivary gland, thyroid and skin $[50,67]$. The clinical utility of $t(1 ; 14)(\mathrm{p} 22 ; \mathrm{q} 32)$ is not yet fully characterized. However, retrospective studies suggest that gastric MALT lymphomas with strong BCL10 nuclear expression or $\mathrm{t}(1 ; 14)(\mathrm{p} 22 ; \mathrm{q} 32)$ do not respond to H. pylori eradication $[81,85]$.

$\mathrm{t}(3 ; 14)(\mathrm{p} 14.1 ; \mathrm{q} 32)$, with rearrangement of IGH and FOXP1, is found in approximately $10 \%$ of MALT lymphomas, mainly from cases arising in the thyroid, ocular adnexa and skin. MALT lymphomas from the stomach and the lung, NMZL and SMZL are typically negative. Most MALT patients carrying $\mathrm{t}(3 ; 14)(\mathrm{p} 14.1 ; \mathrm{q} 32)$ also harbor additional genetic abnormalities, such as trisomy 3 [118].

Several novel chromosome translocations in occasional cases of MALT lymphoma have been described: $\mathrm{t}(3 ; 14)(\mathrm{p} 13 ; \mathrm{q} 32) / F O X P 1-I G H ~[118-120], \mathrm{t}(1 ; 14)(\mathrm{p} 21 ; \mathrm{q} 32) / C N N 3-I G H$, $\mathrm{t}(5 ; 14)(\mathrm{q} 34 ; \mathrm{q} 32) / O D Z 2-I G H, \mathrm{t}(9 ; 14)(\mathrm{p} 24 ; \mathrm{q} 32) / J M J D 2 C-I G H[121], \mathrm{t}(\mathrm{X} ; 14)(\mathrm{p} 11.4 ; \mathrm{q} 32) / G P R 34-$ IGH $[122,123]$ and $\mathrm{t}(1 ; 2)(\mathrm{p} 22 ; \mathrm{p} 12)[103,124]$. These translocations typically juxtapose the oncogene involved to the IGH gene locus, (or with the kappa light chain gene) and cause their over-expression. For instance, FOXP1 over-expression though inhibition of apoptosis and plasma cell differentiation may contribute to the pathogenesis of MALT lymphomas $[125,126]$. The molecular mechanism causing the oncogenic activities of another aforementioned translocation remains to be investigated. Similar to that seen in the four leading translocations, these lesser common translocations are also restricted to specific sites. For instance, translocation $t(3 ; 14) / F O X P 1-I G H$ is found in $7-56 \%$ of thyroid MALT lymphoma cases, $[118,127,128]$, but is not evidenced in non-malignant thyroid disorders (Hashimoto's thyroiditis and benign tissue) [127]. Then, detection of $t(3 ; 14) / F O X P 1-I G H$ may be useful for the differential diagnosis between primary MALT lymphoma of the thyroid and other thyroid disorders [127]. Furthermore, $t(X ; 14)(p 11.4 ; q 32)$ which cause GPR34 over-expression is also restricted to MALT lymphoma of salivary gland, such as MALT lymphomas with GPR34 mutation [122,123]. 
Beyond translocations, a spectrum of chromosomal numerical abnormalities has been described in MALT lymphomas. In the first cytogenetic study in MALT lymphomas from the Isaacson's group, numerical abnormalities of chromosomes 3 and 7 were found in a series of 23 MALT lymphomas [129]. Currently, multiple studies have investigated cytogenetic alterations in MALT lymphomas through several techniques, but in contrast with the aforementioned chromosomal translocations, the role of aneuploidies in lymphomagenesis is less clear and may represent secondary genetic events.

The most common numerical alterations found in MALT lymphomas are trisomy of chromosome 3 or 18, although the frequencies at which these trisomies occur vary markedly with the primary site of disease $[130,131]$. In cytogenetic studies, trisomy 3 is the most common aberration in MALT lymphomas with a frequency from $20-35 \%$ [132,133] to $55-60 \%[129,131,134]$, being mainly observed in gastrointestinal, parotid gland and thyroid. By FISH, the prevalence of trisomy 3 is also heterogeneous, from $5-20 \%[135,136]$ to $43-85 \%$ [131,137-139]. These differences could be the result of different primary sites of MALT lymphoma analyzed but also of different technical approaches. Trisomy 3 can co-occurs with trisomy 18 in up to $30 \%$ of cases [140] but is mutually exclusive with the translocation $\mathrm{t}(11 ; 18)(\mathrm{q} 21 ; \mathrm{q} 21)$. In CGH analysis, partial gain of $3 \mathrm{q}$ affecting the regions $3 \mathrm{q} 21$ 23 and 3q25-29 is reported, indicating that the latter regions are of particular importance and might point to genes involved in the pathogenesis of MZL [141,142].

The genetic mechanisms by which trisomy 3 contributes to lymphomagenesis are not fully clarified. However, the biological effects of chromosomal trisomies are likely to be explained by an enhanced gene dosage effect resulting from larger copy numbers of genes crucial to lymphoma development. Several candidate genes, such as the protooncogene BCL6 [143], the transcription factor FOXP1 [143] or the chemokine receptor CCR4 [144], all found on chromosome 3 , have been linked to lymphomagenesis. In addition, trisomy 3 has been recently associated to cause changes at transcriptome levels similar to that seen in the presence of the BIRC3-MALT1 rearrangement [145]. Of note, patients harboring trisomy 3 were resistant to $H$. pylori eradication treatment in one study [132].

Trisomy 18 has an approximate frequency around 20\% [146,147]. Its presence was associated with a tendency to predict recurrence in the stomach [82] and in the ocular adnexa [110]. By CGH analysis, gain of material of chromosome 18 is the second most frequent alteration, and the most common over-represented region can be delineated to bands 18q21-23 [142].

Other trisomies, such as trisomies 7,12 and others, have been observed non-randomly but less frequently than trisomy 3 or 18. It is worth mentioning that different from other lymphoma types, copy-neutral LOH did not appear to be a common event in MZL [142].

Improvements in the cytogenetic tools have allowed the identification of lesions with relevant role in the lymphomagenesis of MALT lymphomas. Structural aberrations of chromosome 1 frequently involved the chromosomal regions 1p22, 1p34 and 1q21 [129,148] and gains of chromosomes $1 \mathrm{q}$ have been associated with progression or lymphoma relapse [141]. Isolated cases of $8 q$ with a common region in $8 q 22-24$ containing $C-M Y C$ are reported to have rapid disease progression [141]. C-MYC activation via amplification represents a well-known mechanism of disease progression in a wide spectrum of malignant disorders. Loss of material of chromosome 17, especially of 17p, is the most frequent chromosomal loss observed in MZL [141]. Alterations of TP53 have also been described in a considerable proportion of gastric MALT lymphomas $[149,150]$ and have been associated with high-grade transformation [149].

Other genomic imbalances have also been found using array-CGH [142,151,152]. For instance, deletion of TNFAIP3 (A20) was detected in MALT lymphomas of the ocular adnexa $(19 \%)$, thyroid $(11 \%)$, salivary gland $(8 \%)$, and liver $(0.5 \%)$, but not in the lung, stomach, and skin [142,153-156]. In ocular adnexal MALT lymphoma, complete TNFAIP3 inactivation is associated with reduced lymphoma-free survival $[153,157]$. TNFAIP3 can inactivate some NF-kB positive regulators including RIP1/2, TRAF6, Ubc13 and NEMO through removing the K63-linked ubiquitin chain, catalyzing the K48-linked polyubiquitination, 
or direct binding to the linear polyubiquitin chain of its targets [158]. However, TNFAIP3 inactivation alone is not sufficient for malignant transformation but nonetheless may represent a promising future therapeutic target. In addition, deletion of CD274 (PD-L1) are frequently found in MALT lymphomas of the thyroid, together with mutation in up to $68 \%$ of cases (see later) [128].

\section{Mutations}

Although mutational profiling of hematologic neoplasms currently predominates in the area of myeloid neoplasms, there is a growing wealth of literature describing common and highly characteristic genetic alterations in lymphomas. Certain mutations are enriched in specific lymphoma types, and new discoveries continue to emerge at a rapid pace.

The mutational landscape of MALT lymphomas is wide and, in the last decade, has been characterized using high-throughput technologies such as whole exome sequencing, whole genome sequencing and customized NGS panels. The data available to date show frequent lesions affecting chromatin remodeling and transcription regulation, BCR and NF- $\mathrm{B}$ signalling, NOTCH pathways and immune surveillance. Not surprisingly, MALT lymphomas show considerable variations in the incidence and spectrum of genetic mutations among different sites, similar to what happens with translocations. Overall, the most frequent mutations are: TNFAIP3 (29\%; including deletions), CREBBP (22\%), KMT2C (19\%), TET2 and SPEN (17\%, each), KMT2D, LRP1B, and PRDM1 (15\%, each), EP300 (13\%; includes deletion), TNFRSF14 (11\%; includes deletion), NOTCH1/NOTCH2 (11\%, each) and B2M (10\%; includes deletion) [145]. Other mutations detected in other studies have been GPR34 (1-19\%) and CCR6 (1-8\%) [159]. Similar to what occurs in follicular lymphoma and DLCBCL, mutations in KMT2C, KMT2D, CREBBP and EP300 tended to coexist [145] (Figure 1 and Supplementary Table S1).

Some mutations deserve their separate discussion. A study prior the NGS era showed that TP53 was mutated in $18.8 \%$ of gastric MALT lymphoma, and the frequency raised up to $33.3 \%$ in those transformed to DLBCL. Only $2 \%$ of gastric MALT patients showed the concomitance of TP53 mutation and allele loss, but 22\% of DLBCL displayed both TP53 mutation and allele loss, suggesting that TP53 partial inactivation might play a role in the development of low-grade MALT lymphomas, whereas complete inactivation might be associated with high-grade transformation [149]. However, in recent studies using NGS technologies, TP53 has not been usually found to be mutated at presentation in MALT lymphomas from several sites [145,159-161].

MYD88 mutation is infrequent in MALT lymphomas altogether $[160,162,163]$, which is in contrast to primary ocular adnexa MALT lymphoma (OAMZL) where MYD88 mutation, mainly L265P, occurs at frequencies about 6-7\% [159,164,165]. The clinical characteristics are similar in patients with and without MYD88 mutation, including lesion size, lymphoma stage, recurrence, and response to treatment [163]. This gain-of-function mutation enables MYD88 assembling an active complex containing IRAK1 and IRAK4, triggering signaling cascade to activate NF- KB, STAT3 and AP1 transcription factors [166].

As previously mentioned, TNFAIP3 (A20) inactivation by mutation and/or deletion is frequent in MALT lymphomas, in particular in those arising in the ocular adnexa $(29-54 \%)[145,153,167,168]$, although it has been described in other locations such as the dura (36\%) [169], salivary gland (3\%) [159] and thyroid (8\%) [159], among others. The vast majority of TNFAIP3 mutations are deleterious changes (frameshift indels and nonsense mutations), resulting in a truncated protein. Interestingly, TNFAIP3 mutations rarely co-existed with mutations with other genes, supporting their important pathogenetic role in these lymphomas [170]. TNFAIP3 truncation mutants show a substantial impairment in repression of NF-kB activation. TNFAIP3 is a key regulator of inflammation signaling pathways as well as a negative regulator of the NF- $\mathrm{KB}$ pathway, which inhibits NF- $\mathrm{kB}$ activity triggered by signaling from a variety of surface receptors [171]. Thus, TNFAIP3 inactivation can increase the activation of the canonical NF- $\kappa \mathrm{B}$ pathway triggered by signalling from several receptors including BCR, TLR and TNFR1 due to loss of negative regulation on several 
signalling molecules (IKK $\gamma$, TRAF6 and RIP1/2) downstream of their receptors [172-174]. Similarly, TRAF3 inactivation promotes the activation of the non-canonical NF- $\kappa$ B pathway due to impaired control on NIK degradation [175]. Thus, in gastric MALT lymphoma, alterations of TRAF3 and TNFAIP3 were mutually exclusive [176]. Beyond TNFAIP3 and MYD88 mutations, MALT lymphoma shows rare or no mutations in other members of NF-kB pathway such as CD79A, CD79B, CARD11, BIRC3, and TNFRSF11A, which are frequently seen in other B-cell lymphomas with constitutive NF-kB activation.

\section{Ocular adnexa TNFAIP3 (30\%) KMT2D (22\%) ) BCL10 (6-25\%) MYD88 (5-20\%) CREBBP (9-17\%) TBL1XR1 (12\%) JAK3 (11\%) NOTCH1/2 (9\%) TNIP1 (5\%)}

\section{Thyroid} TET2 (86\%) PD-L1 (53\%) TNFRSF14 (53\%) TNFAIP3 (30\%) TNFAIP3 (8\%) CCR6 (8\%)
Skin FAS SLAMF1 SPEN NCOR2

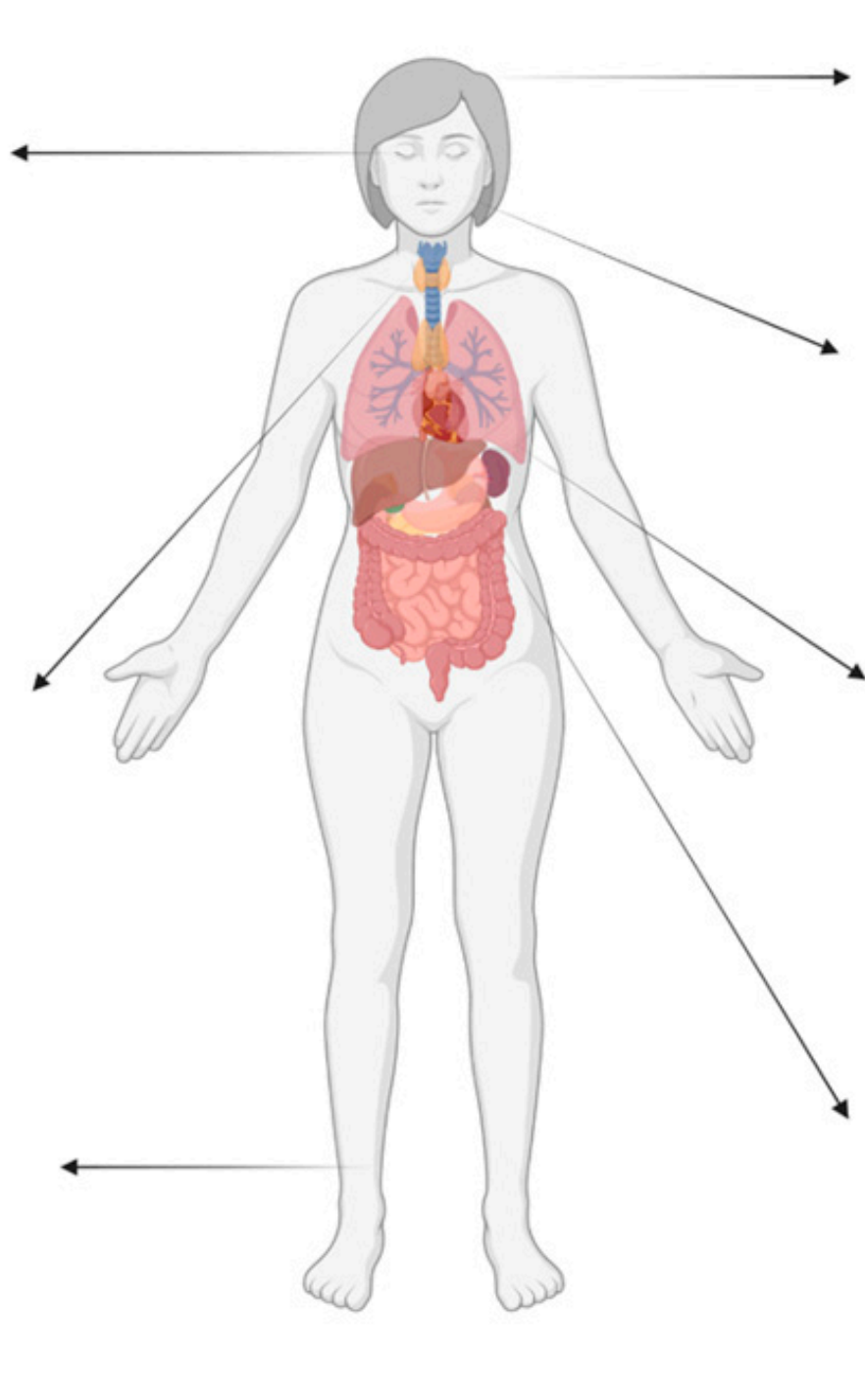

Figure 1. Recurrently mutated genes in MALT lymphoma according to site of origin. Created with BioRender.com.

NOTCH signalling regulates multiple aspects of lymphoid development and function. Although NOTCH inhibits the earliest stage of B lymphopoiesis, it is nevertheless necessary for the development and maintenance of marginal zone lymphocytes [177-179]. However, sustained constitutive NOTCH2 expression alone is insufficient for B-cell lymphomagenesis [180]. Recurrent mutations have been described in NOTCH1 and NOTCH2, but mainly in MALT lymphomas of the ocular adnexa (8-10\%) [160] and dura (29\%) [169]. These mutations mainly resulted in a shortened NOTCH1/2 product lacking TAD or PEST domains, which governs protein stability and degradation [181]. NOTCH1/2 mutations have been associated to aggressive course in some lymphoproliferative disorders [182-186], but the prognostic impact in MALT lymphomas remains to be determined. In a study of gastric 
MALT lymphoma, NOTCH1 mutations were enriched in patients who failed to $H$. pylori eradication [176]. In addition to NOTCH1/2, genetic lesions in additional NOTCH pathway modulators or members, including SPEN (17\%) and DELTEX1, have been identified [145]. These mutations represent activation modifications that are likely to improve NOTCH stability and activity [187].

Several chromatin remodeling and transcriptional regulators are recurrently mutated in MALT lymphoma of different sites, including TBL1XR1, TET2, MLL2/KMT2D and CREBBP $[37,145,159-161,176]$. TBL1XR1 mutations are found in MALT lymphoma of the salivary gland (24\%) [159], ocular adnexa (6-18\%) [159-161,168,188], and in H. pylori-resistant gastric MALT lymphoma (16\%) [176]. In dural extranodal MZL, recurrent TBL1XR1 mutations were only seen in association with NOTCH2 mutations (4/11, 36\%), which might indicate a co-operative role for these mutations in lymphomagenesis [169]. The majority of TBL1XR1 mutations are missense changes affecting regions or residues critical for interaction with NCoR, and may increase TBL1XR1 binding to NCoR and facilitate its degradation, consequently promoting NF- $\mathrm{B}$ and JUN target gene expression $[37,159]$. TET2 mutations are frequently found in MALT lymphoma of the thyroid (62\%) [128] and will be discussed later. Loss of function MLL2/KMT2D mutations have been described in several B-cell lymphomas, and the frequency in MALT lymphomas is variable among studies (5-25\%) [145,160,161]. CREBBP mutations are also frequent observed $(4-22 \%)[37,145,168,188,189]$.

Genetic abnormalities that regulate B and $\mathrm{T}$ cell interactions have also been described in MALT lymphomas. Mutations in TNFRSF14 are frequently seen in those arising in the thyroid $(46-52 \%)[128,159]$ but are also detected in lymphomas from other sites $[37,145,159]$. Most TNFRSF14 mutations are deleterious changes such as nonsense, frameshift alterations, thus most likely inactivating or impairing the protein function. Thereby, TNFRSF14 inactivation may enable malignant B-cells to gain more T-cell help.

As previously discussed, mutations in MALT lymphoma can vary widely depending on the site of origin and, therefore, characteristic locations have been the subject of specific genetic studies.

OAMZL have been the focus of mutation investigations by several groups. Initial studies found recurrent mutations in TNFAIP3 (30\%), MYD88 (5-20\%), and BCL10 (6-25\%), whereas other genes were rarely or not mutated in the cases analyzed $[165,167,190]$ Later, other studies using whole exome sequencing (WES) or customized NGS panels have found mutations in many other genes, albeit with disparate frequencies. These differences could be attributed to regional variances or different sensibilities in the techniques used that could potentially identify subclonal mutations. Using a NGS panel, Johansson et al., besides validation of mutations previously described, found mutations in KMT2D (22\%), NOTCH1 (8\%), NOTCH2 (8\%), TNIP1 (5\%), NFKBIA (4\%), and in other genes at lower frequencies [160]. Using WES, Moody et al., also found a high proportion of patients with TNFAIP3 mutations (36\%), and also recurrent mutations in MYD88 (7\%), TBL1XR1 (6\%), TNFRSF14 (5\%) and TET2 (4\%), besides a few less frequently mutated genes [159]. A further mutation studies identified mutations in additional genes such as CREBBP (9-17\%) [161,168] and $L R P 1 B(6 \%)$ [161]. Interestingly, Vela et al., described that up to 65\% MALT lymphomas harbored mutations of NF- $\mathrm{BB}$ compounds, raising the possibility of precision therapy with BCR inhibitors in refractory cases to conventional treatment. Other genome-wide mutation study identified mutations in JAK3 $(11 \%)$ that were located at sites known to alter the protein function and leading to activation of the JAK/STAT signaling pathway by causing a gain of function of $J A K 3$ [188]. Patients carrying $J A K 3$ mutation had shorter progression free survival, but not reduced overall survival [188]. Identification of activating JAK3 mutations in OAML opens the option for potential precision therapeutics by targeting the JAK/STAT pathway with JAK inhibitors. Other newly identified genes recurrently mutated (5-10\%) included members of the collagen family (COL12A1 and COL1A2) and DOCK8 which is involved in RhoGTPase signaling [188]. 
In SGMZL, G-protein coupled receptors have been found mutated at high frequency $(T B L 1 X R 1=24 \%, G P R 34=19 \%)$ [159]. Interestingly, GPR34 mutation is almost exclusive of this site and mutations in GPR34 and CCR6, both members of the GPCR family, are mutually exclusive [159].

In MALT lymphomas of the thyroid, $\mathrm{Wu}$ et al., have found frequent deleterious mutations of TET2 (86\%), and also mutations in CD274 (53\%), TNFRSF14 (53\%), and TNFAIP3 (30\%) [128]. Both TNFRSF14 and TET2 had a significantly higher variant allele frequency than TNFAIP3, suggesting that TNFAIP3 mutations may occur later than TET2 and TNFRSF14 changes. In patients carrying TET2 mutations, $46 \%$ of them had two mutations and also had a significantly higher number of somatic variants compared with those without. Most TET2 mutations are deleterious alterations, inactivating or impairing its dioxygenase activity, hence its role in DNA demethylation, consequently affecting a wide spectrum of gene expression $[159,191]$. In MALT lymphomas, TET2 inactivation may deregulate the expression of transcriptional factors indispensable for B-cell function, and thus potentially cooperate with receptor signalling, including those by the enhanced T-helper cell signals, indirectly triggered by PD-L1/TNFRSF14 inactivation in malignant B-cells [128].

Kiesewetter et al., have recently investigated the genetic characterization of $H$. pylorinegative gastric MALT lymphoma. In addition to reconfirming that the MALT1 translocation is the most frequent genetic alteration $(39 \%$, most likely $\mathrm{t}(11 ; 18)(\mathrm{q} 21 ; \mathrm{q} 21) / B I R C 3-$ MALT1) and IGH translocation was further seen in $40 \%$ of MALT1-negative cases, mutations in NF-kB signaling pathways were detected in $40 \%$ of cases $(T N F A I P 3=23 \%, C A R D 11=9 \%$, $M A P 3 K 14=9 \%)$. The NF-kB pathway mutations were mutually exclusive from MALT1, albeit not IGH translocation, in total occurring in $86 \%$ of cases [189]. Then, $H$. pylori- negative gastric MALT lymphomas harbor activating mutations that affect both canonical and non-canonical NF-kB pathways [192].

Other studies analyzing the mutational landscape of MALT lymphomas at several sites have been conducted and the list of involved genes keeps growing [193].

\section{MicroRNAs}

MicroRNAs are small non-coding RNAs that modulate gene expression on a posttranscriptional level, playing critical roles in cellular proliferation, apoptosis and differentiation [194,195]. MicroRNAs have important roles as tumor suppressor genes and oncogenes in human malignancies, including in lymphomas [196,197]. Only a few studies have analyzed the role of microRNAs in MALT lymphomas, as diagnostic or prognostic tools.

In H. pylori-associated gastric MALT lymphoma, Craig et al., identified miR-203 as one of the most strongly downregulated miRNAs in comparison with normal lymphoid tissue, suggesting that might be a key player in the transformation from chronic gastritis to MALT lymphoma. In addition, since ABL1 is the target of miR-203, treatment with imatinib and dasatinib (BCR/ABL inhibitors) prevented tumor cell growth [198]. Zhang et al., have found 53 upregulated and 25 downregulated miRNAs in gastric MALT lymphoma. Subsequently, they found upregulated miR-320a, miR-940, and miR-622, and downregulated miR-331-3p and miR-429 miRNA, and after bioinformatic analysis, miR-320a, miR-622, and miR-429 were found likely to be functionally related to each other as they have the same targets, such as C-MYC [199].

miR-142-5p and miR-155 have also been found overexpressed in gastric MALT lymphoma [200]. miR-155, observed during H. pylori infection, may be a potential predictor of resistance to $H$. pylori eradication therapy, independently of API2/MALT1 fusion gene [200]. Inhibition of miRNAs with chemically engineered oligonucleotides, known as "antagomirs", has been shown to work as specific inhibitors of endogenous miRNAs in mice, and they could be used to silence miR-142 and miR-155 for the treatment of gastric MALT lymphomas resistant to $H$. pylori eradication [201,202].

Our group found through analyses of expression of 384 miRNAs that gastric MALT lymphomas are characterized by specific miRNA expression profile, different to that seen in 
chronic gastritis and reactive lymphoid tissue. In addition, 17 differentially miRNAs were expressed between patients carrying or not $\mathrm{t}(11 ; 18)(\mathrm{q} 21 ; \mathrm{q} 21)$. Overexpression of miR-142-3p and miR-155 and downregulation of miR-203 were detected in gastric MALT lymphomas in comparison with chronic gastritis. These finding suggest that expression levels of these miRNAs might be useful for the differential diagnosis between chronic gastritis and gastric MALT lymphoma [203].

In conjunctival MALT lymphoma, some upregulated miRNAs, such as miR-150/155, as well as downregulated miRNAs, such as miR-184, miR-200a/b/c, and miR-205, have also been identified. Dysregulation of the miR-200 family might be involved in the pathogenesis and progression of the lymphoma [204]. The miRNA-200 family inhibits the initiating step of metastasis, the epithelial-mesenchymal transition, by maintaining the epithelial phenotype through directly targeting the transcriptional repressors [205].

All of these miRNAs may be important in the pathomechanisms of MALT lymphoma. However, further studies are needed to clarify their role in the pathogenesis and also its utility in the clinical practice.

\section{Transcriptomics}

Understanding the transcriptome, the complete set of transcripts in a cell and their quantity, is crucial for interpreting the functional elements of the genome and revealing the molecular constituents of cells and tissues, and also for understanding development and disease [206]. Integration of transcriptome data allows for screening of molecular alterations in deregulated B cells, as well as identification of downstream target genes and pathways, shedding light on the understanding of the lymphomagenesis and in the development of novel therapeutics.

The gene expression profile of MALT lymphomas of the lung was analyzed by Chng et al., who described a prominent T-cell signature and a marginal zone/memory B-cell profile [207]. Gene expression profile also revealed one molecular subset characterized by MALT1 translocations, having overexpression of NF-KB pathway genes and enrichment for chemokine signaling pathways (CXCR6 and the ligand of CCR5, CCL5). Another subset displayed increased plasma cells and a prominent plasma cell gene signature [207]. In addition, clusters with different biologic characteristics were identified through the analysis of several genes with very high expression in individual samples, such as cases with MALT1 translocations with high expression of MALT1 and RARA, samples with plasmocytic differentiation having high FKBP11 expression, and cases with high RGS13 expression tending to have trisomy 3 and reactive follicles [207]. CCR4 (3p22.3) was found to be overexpressed in MALT lymphoma bearing trisomy 3 [144].

In 33 MZL cases (18 MALT lymphomas), gains affecting chromosomes $3 q$ and 18 seemed to influence B-cell receptor signaling pathways, cell cycle, Wnt signaling, and apoptosis, whereas genes associated with $3 p$ and 18p gains formed transcripts involved in chemokine and cytokine signaling pathway, ubiquitin proteasome pathway, Ras signaling, and in tight junction regulation [142]. FOXP1 (3p14.1) is overexpressed in a few MALT lymphomas due to its juxtaposition to the immunoglobulin heavy chain gene promoter after chromosomal translocation [118].

Translocation-positive MALT lymphomas (from all sites) are characterized by an enhanced expression of NF-kB target genes, mainly TLR6, chemokine, CD69, CCR2 and $B C L 2$, while translocation-negative cases are characterized by active inflammatory and immune responses, such as interleukin-8, CD86, CD28 and ICOS [208]. The expression of these NF-kB target genes was higher in cases with MYD88 mutation than in those without the mutation, with TLR6 showing a significant difference [165].

Recently, the transcriptome of MALT lymphomas of the lung harbouring BIRC3MALT1 fusion was analysed by Cascione et al. [145], identifying enrichment in MYC target genes, oxidative phosphorylation and DNA repair, genes related to cell cycle, among others. Members of the TNF-receptor superfamily, TNFSF12-TNFSF13 (TWE-PRIL), TNFRSF17 
$(B C M A), L T B$ (lymphotoxin $\beta)$, and CXCR3 were among the most upregulated genes in this subset of patients.

In H. pylori-positive gastric MALT lymphoma cells, Zou et al., have found 15 pathways differentially enriched, including the Wnt, the mTOR, the NOD-like receptor and the Hippo signalling pathways. By deregulating these pathways, $H$. pylori might influence gastric lymphomagenesis through modulating the proliferation of cells, inducing autophagy and fostering inflammatory responses and epithelial mesenchymal transition. By proteomic analysis, they also identified 116 differentially expressed proteins, most of them previously associated with cancer that can be used as biomarkers for lymphoma diagnosis or as potential therapeutic targets [209].

Zhang et al., conducted a study to identify transcriptomic biomarkers in H. pyloriinfected gastritis and gastric cancer or MALT lymphoma [210]. In gastric MALT lymphoma, lncRNA GHRLOS and another 44 mRNA were aberrantly expressed, in agreement with previous studies showing upregulation of lncRNA GHRLOS in different solid tumours [211]. In addition, several molecules such as CXCL13, CCL18, CCL19, CCL 20 and TLR 10 were found to be dysregulated in MALT lymphoma, suggesting that not only modulate $H$. pylori infection but also affect the risk of MALT lymphoma [210].

\section{Epigenetics and Methylation}

Epigenetic alterations such as disturbances of DNA methylation and histone modification are common in B-cell lymphomas, contributing to lymphomagenesis [212]. Alterations involving epigenetic regulators have been described in MALT lymphomas from different sites. Inactivation of chromatin remodeling genes are frequently observed in MALT lymphomas, with the most common mutated genes being TET2, KMT2D, CREBBP, TBL1X1, KMT2C, MT2C, EP300, among others [37,145,156,157,159,167,169,176] (Figure 1 and Supplemental Table S1).

In thyroid MALT lymphomas, as previously mentioned, TET2 mutations were very common with frequencies up to 85.5\% [128,159]. Mutations in TET2 has been associated with increased DNA methylation. Interestingly, genes with hypermethylated promoters in TET2 mutated cases were mostly enriched for the PRC2-complex (EZH2, EED and SUZ12) targets, genes bearing histone $\mathrm{H} 3$ dimethylation at $\mathrm{K} 4(\mathrm{H} 3 \mathrm{~K} 4 \mathrm{me} 2)$ and trimethylation at K27 (H3K27me3). TET2 mutations have been also described (in percentages below 10\%) in the salivary gland, ocular adnexa, stomach, and lung (among others). Since TET2 mutations are associated with higher response rate to demethylating agents in myeloid leukemias, it is reasonable to investigate the role of demethylating agents in patients with TET2 mutated MALT lymphomas.

In OAMZL, the most commonly reported epigenetic mutated gene is KMT2D with frequencies varying from $14 \%$ to $22 \%[160,161,168]$, and in Helicobacter pylori-negative gastric MALT lymphoma, KMT2D (17\%) and CREBBP (14\%) are the two most epigenetic regulator gene mutations [189]. In fact, as previously discussed, mutations in CREBBP are found in $4-22 \%$ of MALT lymphomas [37,145,168,188,189]. The CREBBP gene encodes a lysine acetyltransferase (KAT) protein that activates gene expression through acetylation of histone $\mathrm{H} 3$ lysine 18 (H3K18Ac), histone H3 lysine 27 (H3K27Ac), and other residues. KAT domain mutation of $C R E B B P$ inhibit its catalytic activity and leads to a dominant-repressive effect by preventing the participation of redundant acetyltransferases in transactivation complexes, leading to loss of antagonism to BCL6-mediated gene repression and reduced expression of antigen presentation and interferon signaling genes in germinal-center lymphomas [213]. By using HDAC3-selective inhibitors, these genes can be restored in CREBBP mutant cells [214]. This suggests that epigenetic modulation of immune response with HDAC3 inhibitors (or EZH2 inhibitors) may be explored in CREBBP-mutant MALT lymphomas, alone or in combination with PD1/PD-L1 blockade (to prevent interferon-induced adaptive immune suppression).

While classical mutations in genes are region-limited, epimutations often occur early in cancer development and have a genome-wide impact. CpG island hypermethylation of 
TP15 and TP73 genes was detected more frequently in gastric MALT lymphomas than in gastric or nodal DLBCL [215]. Hypermethylation of DAP-k (72.2\%), GSTP1 (50\%), MGMT $(27.2 \%)$ and TP73 (9\%) have been found in MALT lymphomas [216]. Inactivation of the extrinsic pathway of apoptosis through DAP-k methylation, genetic instability favoring acquisition of DNA point mutation caused by MGMT hypermethylation and scavenging reactive oxygen species causing an inflammatory microenvironment by GSTP1 inactivation through promoter methylation may represent pathogenetic events in gastric MALT lymphomagenesis [216]. In MALT lymphomas of the lung, p16 gene methylation was detected at a frequently of $60 \%$, similar to that found in DLBCL $(55 \%)$, and was not correlated with API2-MALT1 fusion, serum LDH, clinical stage, and increased large cells [217]. The same group showed in MALT lymphoma of the skin that hypermethylation of the CpG islands of the tumor suppressor genes DAPK and TP16 ${ }^{I N K 4 a}$ was frequently observed at its initial presentation, but not at tumor progression [72]. These observations suggest that hypermethylation of various genes may be early molecular events that contribute in early MALT lymphomagenesis.

Furthermore, aberrant methylation has also been implicated in tumor progression. Dugge et al., investigated the DNA methylation changes associated with progression of gastric MALT lymphoma through genome-wide DNA methylation profiling and observed that 7698 CpG loci associated with 2419 genes were significantly differentially methylated during gastric MALT lymphoma progression [218]. Among these loci, enrichment of CpGs associated with the promoter was seen and the loci were also enriched in the CpGrich regions, with most of loci being located within CpG islands [219]. As CpG islands are sites of transcription initiation whose methylation affects chromatin structure, the differentially methylated loci locate to regions involved in transcriptional regulation, which may influence the gene expression. However, no significant changes in the RNA expression levels in the majority of differentially methylated genes were identified. Nevertheless, morphological differences were reflected between gastric MALT lymphoma transformed to large cell lymphoma by characteristic DNA methylation profiles

Since epigenetic changes are potentially reversible, epigenetic therapy, both alone or in combination with established treatment regimens, has a promising future, leading to potentially less toxic and more effective approaches that standard chemotherapy.

\section{Applicability in the Real-World}

Davis et al., have explored the clinical and practical diagnostic utility of a targeted NGS within mature lymphoid neoplasms (MLN) [220]. They studied the integration of a 40 gene lymphoid panel in 534 MLN during 1-year into the routine comprehensive characterization of lymphomas and found that this practice is not of current diagnostic value in most cases. Improved diagnostic outcomes that led to changing, refining, and facilitating diagnoses were evident in only $5.5 \%$ of cases when such testing was applied empirically. Nevertheless, there remains the potential for better outcomes if the practice is standardized [220]. In MZL, from 52 cases, 25 disease-associated variants, 10 variants of uncertain significance, 14 no variant and 3 QLF (qualitative failure due to inadequate DNA quality) were observed. In this study, refinements of diagnoses were most frequently reported due to either the presence or absence of MYD88 mutations in distinguishing LPL from MZL or the presence of NOTCH2 and TNFAIP3 mutations in favoring a diagnosis of MZL over LPL [220].

Pillonel et al., reported a 3-year experience with a 68-gene lymphoma NGS panel applied to 80 cases [221]. The analysis was useful in most cases, helping to confirm or support diagnoses in 35 of 50 histologically difficult cases. However, while it may appear that the diagnostic utility rate is much higher than reported by Davis (70\% vs. 5.5\%), it should be noted that cases included in the Swiss group were highly selected, based upon a predetermined perceived need for mutational analysis, resulting in only $\sim 1 \%$ of all cases being analyzed. NGS analysis was useful to detect potentially therapy or matching drugs were still not available/accessible. However, no patients directly benefited from a matched targeted therapy, which might be mainly linked to the lack of approved agents in lymphoma 
management. Recently, tazemetostat, a methyltransferase inhibitor, has been approved by FDA for relapsed or refractory follicular lymphoma whose tumors are positive for an EZH2 mutation and who have received at least 2 prior systemic therapies and also for relapsed or refractory follicular lymphoma who have no suitable alternative treatment options [222]. This precision therapy will change the usefulness of NGS panels for lymphomas in the near future.

Currently, NGS analysis is not generally applied to patients as first-line investigational approach, but rather applicable to further define diagnosis in highly selected otherwise equivocal instances and/or to identify mutations that will guide treatment decisions in cases in which standard treatment options are scarce or suboptimal [221].

\section{Conclusions}

MALT lymphomas are a diverse group of lymphoid neoplasms that exhibit a wide range of genetic features depending on the site of origin. Despite the fact that MALT lymphoma of different anatomic locations shares many common clinicopathological characteristics, there are substantial variances in the aetiology, Ig gene usage, and acquired genetic alterations. Then, it is crucial to better characterize the somatic mutation profile of MALT lymphomas and unravel their molecular oncogenic complexity applying the latest NGS platforms.

Excitingly, the majority of the genetic changes affects NF-KB signal pathway-related genes, resulting in constitutive NF-kB pathway activation. At the same time, since targeted gene sequencing panels have been recently applied to MALT lymphomas, we have learned that other genes are also frequently affected such as those involved in chromatin remodeling, $\mathrm{BCR} / \mathrm{TLR}$ and NOTCH pathways. The growing knowledge of its genetic landscape, methylation, and transcriptome features raises the possibility of applying new agents to treat a subset of MALT lymphoma patients and also push forward the concept of precision medicine in this type of lymphoma.

Supplementary Materials: The following are available online at https: / www.mdpi.com/article/ 10.3390/cancers14010176/s1, Table S1. Recurrently mutated genes in MALT lymphomas.

Author Contributions: Study concept and design: A.S.; methodology, literature review, data collection, analysis and interpretation: J.J.R.-S. and A.S.; writing-original draft manuscript: J.J.R.-S. and A.S.; figure editing: J.J.R.-S.; review-original final manuscript: J.J.R.-S. and A.S. All authors have read and agreed to the published version of the manuscript. We apologize to authors of several high-profile articles whose work was not included owing to space limitations.

Funding: This research received no external funding.

Acknowledgments: This study was supported in part by ISCIII, FIS-FEDER PI19/00034, GILEAD GLD18/00117, 2017SGR205, PT17/0015/0011 and Xarxa de Banc de Tumors de Catalunya.

Conflicts of Interest: The authors declare no conflict of interest.

\section{References}

1. Isaacson, P.; Wright, D.H. Malignant lymphoma of mucosa-associated lymphoid tissue. A distinctive type of B-cell lymphoma. Cancer 1983, 52, 1410-1416. [CrossRef]

2. Swerdlow, S.H.; World Health Organization, International Agency for Research on Cancer. WHO Classification of Tumours of Haematopoietic and Lymphoid Tissues; World Health Organization: Geneva, Switzerland; IARC: Lyon, France, 2017.

3. Teras, L.R.; DeSantis, C.E.; Cerhan, J.R.; Morton, L.M.; Jemal, A.; Flowers, C.R. 2016 US lymphoid malignancy statistics by World Health Organization subtypes. CA Cancer J. Clin. 2016, 66, 443-459. [CrossRef]

4. Cerhan, J.R.; Habermann, T.M. Epidemiology of Marginal Zone Lymphoma. Ann. Lymphoma 2021, 5, 1. [CrossRef] [PubMed]

5. Luminari, S.; Cesaretti, M.; Marcheselli, L.; Rashid, I.; Madrigali, S.; Maiorana, A.; Federico, M. Decreasing incidence of gastric MALT lymphomas in the era of anti-Helicobacter pylori interventions: Results from a population-based study on extranodal marginal zone lymphomas. Ann. Oncol. 2010, 21, 855-859. [CrossRef] [PubMed]

6. Zucca, E.; Bertoni, F. The spectrum of MALT lymphoma at different sites: Biological and therapeutic relevance. Blood 2016, 127, 2082-2092. [CrossRef]

7. Isaacson, P.G.; Du, M.-Q. MALT lymphoma: From morphology to molecules. Nat. Rev. Cancer 2004, 4, 644-653. [CrossRef] 
8. Ferreri, A.J.M.; Govi, S.; Ponzoni, M. Marginal zone lymphomas and infectious agents. Semin. Cancer Biol. 2013, 23, 431-440. [CrossRef]

9. Zucca, E.; Conconi, A.; Pedrinis, E.; Cortelazzo, S.; Motta, T.; Gospodarowicz, M.K.; Patterson, B.J.; Ferreri, J.M.; Ponzoni, M.; Devizzi, L.; et al. Nongastric marginal zone B-cell lymphoma of mucosa-associated lymphoid tissue. Arbor Cienc. Pensam. Cult. 2003, 101, 2489-2495. [CrossRef]

10. Isaacson, P.G. Gastrointestinal lymphoma. Hum. Pathol. 1994, 25, 1020-1029. [CrossRef]

11. Morgner, A.; Lehn, N.; Andersen, L.P.; Thiede, C.; Bennedsen, M.; Trebesius, K.; Neubauer, B.; Neubauer, A.; Stolte, M.; Bayerdörffer, E. Helicobacter heilmannii-associated primary gastric low-grade MALT lymphoma: Complete remission after curing the infection. Gastroenterology 2000, 118, 821-828. [CrossRef]

12. Ponzoni, M.; Ferreri, A.J.M.; Guidoboni, M.; Lettini, A.A.; Cangi, M.G.; Pasini, E.; Sacchi, L.; Pecciarini, L.; Grassi, S.; Dal Cin, E.; et al. Chlamydia Infection and Lymphomas: Association Beyond Ocular Adnexal Lymphomas Highlighted by Multiple Detection Methods. Clin. Cancer Res. 2008, 14, 5794-5800. [CrossRef]

13. Ferreri, A.J.M.; Guidoboni, M.; Ponzoni, M.; De Conciliis, C.; Dell'Oro, S.; Fleischhauer, K.; Caggiari, L.; Lettini, A.A.; Dal Cin, E.; Ieri, R.; et al. Evidence for an association between Chlamydia psittaci and ocular adnexal lymphomas. J. Natl. Cancer Inst. 2004, 96, 586-594. [CrossRef]

14. Goodlad, J.R.; Davidson, M.M.; Hollowood, K.; Ling, C.; MacKenzie, C.; Christie, I.; Batstone, P.J.; Ho-Yen, D.O. Primary cutaneous B-cell lymphoma and Borrelia burgdorferi infection in patients from the highlands of Scotland. Am. J. Surg. Pathol. 2000, 24, 1279-1285. [CrossRef]

15. Cerroni, L.; Zöchling, N.; Pütz, B.; Kerl, H. Infection by Borrelia burgdorferi and cutaneous B-cell lymphoma. J. Cutan. Pathol. 1997, 24, 457-461. [CrossRef]

16. Lecuit, M.; Abachin, E.; Martin, A.; Poyart, C.; Pochart, P.; Suarez, F.; Bengoufa, D.; Feuillard, J.; Lavergne, A.; Gordon, J.I.; et al. Immunoproliferative Small Intestinal Disease Associated with Campylobacter jejuni. N. Engl. J. Med. 2004, 350, 239-248. [CrossRef] [PubMed]

17. Adam, P.; Czapiewski, P.; Colak, S.; Kosmidis, P.; Tousseyn, T.; Sagaert, X.; Boudova, L.; Okoń, K.; Morresi-Hauf, A.; Agostinelli, C.; et al. Prevalence of Achromobacter xylosoxidans in pulmonary mucosa-associated lymphoid tissue lymphoma in different regions of Europe. Br. J. Haematol. 2014, 164, 804-810. [CrossRef] [PubMed]

18. Wöhrer, S.; Troch, M.; Streubel, B.; Zwerina, J.; Skrabs, C.; Formanek, M.; Hauff, W.; Hoffmann, M.; Müllauer, L.; Chott, A.; et al MALT lymphoma in patients with autoimmune diseases: A comparative analysis of characteristics and clinical course. Leukemia 2007, 21, 1812-1818. [CrossRef] [PubMed]

19. Galanina, N.; Bejar, R.; Choi, M.; Goodman, A.; Wieduwilt, M.; Mulroney, C.; Kim, L.; Yeerna, H.; Tamayo, P.; Vergilio, J.A.; et al. Comprehensive genomic profiling reveals diverse but actionable molecular portfolios across hematologic malignancies: Implications for next generation clinical trials. Cancers 2019, 11, 11. [CrossRef] [PubMed]

20. Hussell, T.; Isaacson, P.G.; Spencer, J. Proliferation and differentiation of tumour cells from B-cell lymphoma of mucosa-associated lymphoid tissue in vitro. J. Pathol. 1993, 169, 221-227. [CrossRef] [PubMed]

21. Noy, A.; de Vos, S.; Thieblemont, C.; Martin, P.; Flowers, C.R.; Morschhauser, F.; Collins, G.P.; Ma, S.; Coleman, M.; Peles, S.; et al Targeting Bruton tyrosine kinase with ibrutinib in relapsed/refractory marginal zone lymphoma. Blood 2017, 129, 2224-2232. [CrossRef]

22. Aarts, W.M.; Bende, R.J.; Steenbergen, E.J.; Kluin, P.M.; Ooms, E.C.M.; Pals, S.T.; Van Noesel, C.J.M. Variable heavy chain gene analysis of follicular lymphomas: Correlation between heavy chain isotype expression and somatic mutation load. Blood 2000, 95, 2922-2929. [CrossRef]

23. Hallas, C.; Greiner, A.; Peters, K.; Müller-Hermelink, H.K. Immunoglobulin V(H) genes of high-grade mucosa-associated lymphoid tissue lymphomas show a high load of somatic mutations and evidence of antigen-dependent affinity maturation. Lab. Investig. 1998, 78, 277-287. [PubMed]

24. Qin, Y.; Greiner, A.; Trunk, M.J.F.; Schmausser, B.; Ott, M.M.; Müller-Hermelink, H.K. Somatic Hypermutation in Low-Grade Mucosa-Associated Lymphoid Tissue-Type B-Cell Lymphoma. Blood 1995, 86, 3528-3534. [CrossRef] [PubMed]

25. Bende, R.J.; Aarts, W.M.; Riedl, R.G.; De Jong, D.; Pals, S.T.; Van Noesel, C.J.M. Among B cell non-Hodgkin's lymphomas, MALT lymphomas express a unique antibody repertoire with frequent rheumatoid factor reactivity. J. Exp. Med. 2005, 201, 1229-1241. [CrossRef]

26. Du, M.; Diss, T.C.; Xu, C.; Peng, H.; Isaacson, P.G.; Pan, L. Ongoing mutation in MALT lymphoma immunoglobulin gene suggests that antigen stimulation plays a role in the clonal expansion. Leukemia 1996, 10, 1190-1197.

27. Bertoni, F.; Cazzaniga, G.; Bosshard, G.; Roggero, E.; Barbazza, R.; De Boni, M.; Capella, C.; Pedrinis, E.; Cavalli, F.; Biondi, A.; et al. Immunoglobulin heavy chain diversity genes rearrangement pattern indicates that MALT-type gastric lymphoma B cells have undergone an antigen selection process. Br. J. Haematol. 1997, 97, 830-836. [CrossRef]

28. Tierens, A.; Delabie, J.; Pittaluga, S.; Driessen, A.; De Wolf-Peeters, C.; DeWolf-Peeters, C. Mutation analysis of the rearranged immunoglobulin heavy chain genes of marginal zone cell lymphomas indicates an origin from different marginal zone B lymphocyte subsets. Blood 1998, 91, 2381-2386. [CrossRef] [PubMed]

29. Xochelli, A.; Bikos, V.; Polychronidou, E.; Galigalidou, C.; Agathangelidis, A.; Charlotte, F.; Moschonas, P.; Davis, Z.; Colombo, M.; Roumelioti, M.; et al. Disease-biased and shared characteristics of the immunoglobulin gene repertoires in marginal zone B cell lymphoproliferations. J. Pathol. 2019, 247, 416-421. [CrossRef] 
30. Craig, V.J.; Arnold, I.; Gerke, C.; Huynh, M.Q.; Wündisch, T.; Neubauer, A.; Renner, C.; Falkow, S.; Müller, A. Gastric MALT lymphoma B cells express polyreactive, somatically mutated immunoglobulins. Blood 2010, 115, 581-591. [CrossRef]

31. Du, M.-Q. Mucosa-associated lymphoid tissue lymphoma of various sites: Common molecular mechanisms but different players Ann. Lymphoma 2020, 4, 8. [CrossRef]

32. Bende, R.J.; Janssen, J.; Beentjes, A.; Wormhoudt, T.A.M.; Wagner, K.; Haacke, E.A.; Kroese, F.G.M.; Guikema, J.E.; van Noesel, C.J.M. Salivary gland MALT lymphomas of Sjögren's syndrome patients in majority express rheumatoid factors affinity-selected for IgG. Arthritis Rheumatol. 2020, in press. [CrossRef]

33. Hoogeboom, R.; Bende, R.J.; Van Noesel, C.J.M. MALT lymphoma-derived rheumatoid factors are nonpolyreactive high-affinity antibodies. Blood 2010, 116, 1818-1819. [CrossRef]

34. Coupland, S.E.; Foss, H.D.; Anagnostopoulos, I.; Hummel, M.; Stein, H. Immunoglobulin V(H) gene expression among extranodal marginal zone B-cell lymphomas of the ocular adnexa. Investig. Ophthalmol. Vis. Sci. 1999, 40, 555-562.

35. Mannami, T.; Yoshino, T.; Oshima, K.; Takase, S.; Kondo, E.; Ohara, N.; Nakagawa, H.; Ohtsuki, H.; Harada, M.; Akagi, T. Clinical, histopathological, and immunogenetic analysis of ocular adnexal lymphoproliferative disorders: Characterization of MALT lymphoma and reactive lymphoid hyperplasia. Mod. Pathol. 2001, 14, 641-649. [CrossRef]

36. Bahler, D.W.; Szankasi, P.; Kulkarni, S.; Tubbs, R.R.; Cook, J.R.; Swerdlow, S.H. Use of similar immunoglobulin VH gene segments by MALT lymphomas of the ocular adnexa. Mod. Pathol. 2009, 22, 833-838. [CrossRef]

37. Moody, S.; Escudero-Ibarz, L.; Wang, M.; Clipson, A.; Ruiz, E.O.; Dunn-Walters, D.; Xue, X.; Zeng, N.; Robson, A.; Chuang, S.-S.; et al. Significant association between TNFAIP3 inactivation and biased immunoglobulin heavy chain variable region 4-34 usage in mucosa-associated lymphoid tissue lymphoma. J. Pathol. 2017, 243, 3-8. [CrossRef]

38. van Maldegem, F.; Wormhoudt, T.A.M.; Mulder, M.M.S.; Oud, M.E.C.M.; Schilder-Tol, E.; Musler, A.R.; Aten, J.; Saeed, P.; Kersten, M.J.; Pals, S.T.; et al. Chlamydia psittaci-negative ocular adnexal marginal zone B-cell lymphomas have biased VH434 immunoglobulin gene expression and proliferate in a distinct inflammatory environment. Leukemia 2012, 26, 1647-1653. [CrossRef] [PubMed]

39. Dagklis, A.; Ponzoni, M.; Govi, S.; Cangi, M.G.; Pasini, E.; Charlotte, F.; Vino, A.; Doglioni, C.; Davi, F.; Lossos, I.S.; et al. Immunoglobulin gene repertoire in ocular adnexal lymphomas: Hints on the nature of the antigenic stimulation. Leukemia 2012, 26, 814-821. [CrossRef] [PubMed]

40. Richardson, C.; Chida, A.S.; Adlowitz, D.; Silver, L.; Fox, E.; Jenks, S.A.; Palmer, E.; Wang, Y.; Heimburg-Molinaro, J.; Li, Q.-Z.; et al. Molecular Basis of 9G4 B Cell Autoreactivity in Human Systemic Lupus Erythematosus. J. Immunol. 2013, 191, 4926-4939. [CrossRef] [PubMed]

41. Zhu, D.; Ikpatt, O.F.; Dubovy, S.R.; Lossos, C.; Natkunam, Y.; Chapman-Fredricks, J.R.; Fan, Y.-S.; Lossos, I.S. Molecular and genomic aberrations in Chlamydophila psittaci negative ocular adnexal marginal zone lymphomas. Am. J. Hematol. 2013, 88, 730-735. [CrossRef]

42. Thiede, C.; Alpen, B.; Morgner, A.; Schmidt, M.; Ritter, M.; Ehninger, G.; Stolte, M.; Bayerdörffer, E.; Neubauer, A. Ongoing somatic mutations and clonal expansions after cure of Helicobacter pylori infection in gastric mucosa-assiociated lymphoid tissue B-cell lymphoma. J. Clin. Oncol. 1998, 16, 3822-3831. [CrossRef] [PubMed]

43. Michaeli, M.; Tabibian-Keissar, H.; Schiby, G.; Shahaf, G.; Pickman, Y.; Hazanov, L.; Rosenblatt, K.; Dunn-Walters, D.K.; Barshack, I.; Mehr, R. Immunoglobulin gene repertoire diversification and selection in the stomach—From gastritis to gastric lymphomas. Front. Immunol. 2014, 5, 264. [CrossRef]

44. Hashimoto, Y.; Nakamura, N.; Kuze, T.; Ono, N.; Abe, M. Multiple lymphomatous polyposis of the gastrointestinal tract is a heterogenous group that includes mantle cell lymphoma and follicular lymphoma: Analysis of somatic mutation of immunoglobulin heavy chain gene variable region. Hum. Pathol. 1999, 30, 581-587. [CrossRef]

45. Matsubara, J.; Ono, M.; Negishi, A.; Ueno, H.; Okusaka, T.; Furuse, J.; Furuta, K.; Sugiyama, E.; Saito, Y.; Kaniwa, N.; et al. Identification of a predictive biomarker for hematologic toxicities of gemcitabine. J. Clin. Oncol. 2009, 27, 2261-2268. [CrossRef] [PubMed]

46. Sakuma, H.; Nakamura, T.; Uemura, N.; Chiba, T.; Sugiyama, T.; Asaka, M.; Akamatsu, T.; Ueda, R.; Eimoto, T.; Goto, H.; et al. Immunoglobulin VH gene analysis in gastric MALT lymphomas. Mod. Pathol. 2007, 20, 460-466. [CrossRef] [PubMed]

47. Thieblemont, C.; Bertoni, F.; Copie-Bergman, C.; Ferreri, A.J.M.; Ponzoni, M. Chronic inflammation and extra-nodal marginal-zone lymphomas of MALT-type. Semin. Cancer Biol. 2014, 24, 33-42. [CrossRef] [PubMed]

48. Zhu, D.; Bhatt, S.; Lu, X.; Guo, F.; Veelken, H.; Hsu, D.K.; Liu, F.T.; Alvarez Cubela, S.; Kunkalla, K.; Vega, F.; et al. Chlamydophila psittaci-negative ocular adnexal marginal zone lymphomas express self polyreactive B-cell receptors. Leukemia 2015, 29, 1587-1599. [CrossRef]

49. Du, M.Q. MALT lymphoma: Recent advances in aetiology and molecular genetics. J. Clin. Exp. Hematop. 2007, 47, 31-42. [CrossRef]

50. Streubel, B.; Simonitsch-Klupp, I.; Müllauer, L.; Lamprecht, A.; Huber, D.; Siebert, R.; Stolte, M.; Trautinger, F.; Lukas, J.; Püspök, A.; et al. Variable frequencies of MALT lymphoma-associated genetic aberrations in MALT lymphomas of different sites. Leukemia 2004, 18, 1722-1726. [CrossRef]

51. Farinha, P.; Gascoyne, R.D. Molecular Pathogenesis of Mucosa-Associated Lymphoid Tissue Lymphoma. J. Clin. Oncol. 2005, 23, 6370-6378. [CrossRef] 
52. Ruefli-Brasse, A.A.; French, D.M.; Dixit, V.M. Regulation of NF-кB-Dependent Lymphocyte Activation and Development by Paracaspase. Science 2003, 302, 1581-1584. [CrossRef] [PubMed]

53. Lucas, P.C.; Yonezumi, M.; Inohara, N.; McAllister-Lucas, L.M.; Abazeed, M.E.; Chen, F.F.; Yamaoka, S.; Seto, M.; Núñez, G. Bcl10 and MALT1, Independent Targets of Chromosomal Translocation in MALT Lymphoma, Cooperate in a Novel NF- $\mathrm{kB}$ Signaling Pathway. J. Biol. Chem. 2001, 276, 19012-19019. [CrossRef] [PubMed]

54. Akagi, T.; Motegi, M.; Tamura, A.; Suzuki, R.; Hosokawa, Y.; Suzuki, H.; Ota, H.; Nakamura, S.; Morishima, Y.; Taniwaki, M.; et al. A novel gene, MALT1 at 18q21, is involved in $\mathrm{t}(11 ; 18)(\mathrm{q} 21 ; \mathrm{q} 21)$ found in low-grade B-cell lymphoma of mucosa-associated lymphoid tissue. Oncogene 1999, 18, 5785-5794. [CrossRef]

55. Morgan, J.; Yin, Y.; Borowsky, A.; Kuo, F.; Nourmand, N.; Koontz, J.; Reynolds, C.; Soreng, L.; Griffin, C.; Graeme-Cook, F.; et al. Breakpoints of the $t(11 ; 18)(q 21 ; q 21)$ in mucosa-associated lymphoid tissue (MALT) lymphoma lie within or near the previously undescribed gene MALT1 in chromosome 18. Cancer Res. 1999, 59, 6205-6213. [PubMed]

56. Baens, M.; Maes, B.; Steyls, A.; Geboes, K.; Marynen, P.; De Wolf-Peeters, C. The product of the t(11;18), an API2-MLT fusion, marks nearly half of gastric MALT type lymphomas without large cell proliferation. Am. J. Pathol. 2000, 156, 1433-1439. [CrossRef]

57. Sanchez-Izquierdo, D.; Buchonnet, G.; Siebert, R.; Gascoyne, R.D.; Climent, J.; Karran, L.; Marin, M.; Blesa, D.; Horsman, D.; Rosenwald, A.; et al. MALT1 is deregulated by both chromosomal translocation and amplification in B-cell non-Hodgkin lymphoma. Blood 2003, 101, 4539-4546. [CrossRef] [PubMed]

58. Ruland, J.; Duncan, G.S.; Wakeham, A.; Mak, T.W. Differential requirement for Malt1 in T and B cell antigen receptor signaling. Immunity 2003, 19, 749-758. [CrossRef]

59. Remstein, E.D.; James, C.D.; Kurtine, P.J. Incidence and subtype specificity of API2-MALT1 fusion translocations in extranodal, nodal, and splenic marginal zone lymphomas. Am. J. Pathol. 2000, 156, 1183-1188. [CrossRef]

60. Lucas, P.C.; Kuffa, P.; Gu, S.; Kohrt, D.; Kim, D.S.L.; Siu, K.; Jin, X.; Swenson, J.; McAllister-Lucas, L.M. A dual role for the API2 moiety in API2-MALT1-dependent NF-kappaB activation: Heterotypic oligomerization and TRAF2 recruitment. Oncogene 2007, 26, 5643-5654. [CrossRef]

61. Zhou, H.; Du, M.-Q.; Dixit, V.M. Constitutive NF-??B activation by the $\mathrm{t}(11 ; 18)(\mathrm{q} 21 ; \mathrm{q} 21)$ product in MALT lymphoma is linked to deregulated ubiquitin ligase activity. Cancer Cell 2005, 7, 425-431. [CrossRef]

62. Baens, M.; Fevery, S.; Sagaert, X.; Noels, H.; Hagens, S.; Broeckx, V.; Billiau, A.D.; De Wolf-Peeters, C.; Marynen, P. Selective expansion of marginal zone B cells in Emicro-API2-MALT1 mice is linked to enhanced IkappaB kinase gamma polyubiquitination. Cancer Res. 2006, 66, 5270-5277. [CrossRef]

63. Dierlamm, J.; Baens, M.; Wlodarska, I.; Stefanova-Ouzounova, M.; Hernandez, J.M.; Hossfeld, D.K.; De Wolf-Peeters, C.; Hagemeijer, A.; Van den Berghe, H.; Marynen, P. The Apoptosis Inhibitor Gene API2 and a Novel 18q Gene, MLT, Are Recurrently Rearranged in the $\mathrm{t}(11 ; 18)(\mathrm{q} 21 ; \mathrm{q} 21)$ Associated With Mucosa-Associated Lymphoid Tissue Lymphomas. Blood 1999, 93, 3601-3609. [CrossRef]

64. Rosebeck, S.; Madden, L.; Jin, X.; Gu, S.; Apel, I.J.; Appert, A.; Hamoudi, R.A.; Noels, H.; Sagaert, X.; Loo, P.V.; et al. Cleavage of NIK by the API2-MALT1 fusion oncoprotein leads to noncanonical NF-kappaB activation. Science 2011, 331, 468-472. [CrossRef]

65. Nie, Z.; Du, M.-Q.; McAllister-Lucas, L.M.; Lucas, P.C.; Bailey, N.G.; Hogaboam, C.M.; Lim, M.S.; Elenitoba-Johnson, K.S.J. Conversion of the LIMA1 tumour suppressor into an oncogenic LMO-like protein by API2-MALT1 in MALT lymphoma. Nat. Commun. 2015, 6, 5908. [CrossRef]

66. Streubel, B.; Seitz, G.; Stolte, M.; Birner, P.; Chott, A.; Raderer, M. MALT lymphoma associated genetic aberrations occur at different frequencies in primary and secondary intestinal MALT lymphomas. Gut 2006, 55, 1581-1585. [CrossRef]

67. Remstein, E.D.; Kurtin, P.J.; Einerson, R.R.; Paternoster, S.F.; Dewald, G.W. Primary pulmonary MALT lymphomas show frequent and heterogeneous cytogenetic abnormalities, including aneuploidy and translocations involving API2 and MALT1 and IGH and MALT1. Leukemia 2004, 18, 156-160. [CrossRef]

68. Gallardo, F.; Bellosillo, B.; Espinet, B.; Pujol, R.M.; Estrach, T.; Servitje, O.; Romagosa, V.; Barranco, C.; Boluda, S.; García, M.; et al Aberrant nuclear BCL10 expression and lack of $\mathrm{t}(11 ; 18)(\mathrm{q} 21 ; \mathrm{q} 21)$ in primary cutaneous marginal zone B-cell lymphoma. Hum. Pathol. 2006, 37, 867-873. [CrossRef]

69. Schreuder, M.I.; Hoefnagel, J.J.; Jansen, P.M.; van Krieken, J.H.J.M.; Willemze, R.; Hebeda, K.M. FISH analysis of MALT lymphoma-specific translocations and aneuploidy in primary cutaneous marginal zone lymphoma. J. Pathol. 2005, 205, 302-310. [CrossRef]

70. Dierlamm, J.; Baens, M.; Stefanova-Ouzounova, M.; Hinz, K.; Wlodarska, I.; Maes, B.; Steyls, A.; Driessen, A.; Verhoef, G.; Gaulard, P.; et al. Detection of $\mathrm{t}(11 ; 18)(\mathrm{q} 21 ; \mathrm{q} 21)$ by interphase fluorescence in situ hybridization using API2 and MLTspecific probes. Blood 2000, 96, 2215-2218. [CrossRef]

71. Murga Penas, E.M.; Hinz, K.; Röser, K.; Copie-Bergman, C.; Wlodarska, I.; Marynen, P.; Hagemeijer, A.; Gaulard, P.; Löning, T.; Hossfeld, D.K.; et al. Translocations $\mathrm{t}(11 ; 18)(\mathrm{q} 21 ; \mathrm{q} 21)$ and $\mathrm{t}(14 ; 18)(\mathrm{q} 32 ; \mathrm{q} 21)$ are the main chromosomal abnormalities involving MLT/MALT1 in MALT lymphomas. Leukemia 2003, 17, 2225-2229. [CrossRef]

72. Takino, H.; Li, C.; Hu, S.; Kuo, T.-T.; Geissinger, E.; Muller-Hermelink, H.K.; Kim, B.; Swerdlow, S.H.; Inagaki, K. Primary cutaneous marginal zone B-cell lymphoma: A molecular and clinicopathological study of cases from Asia, Germany, and the United States. Mod. Pathol. 2008, 21, 1517-1526. [CrossRef] 
73. Dierlamm, J.; Murga Penas, E.; Daibata, M.; Tagushi, H.; Hinz, K.; Baens, M.; Cools, J.; Schilling, G.; Michaux, L.; Marynen, P.; et al. The novel $\mathrm{t}(11 ; 12 ; 18)(\mathrm{q} 21 ; \mathrm{q} 13 ; \mathrm{q} 21)$ represents a variant translocation of the $\mathrm{t}(11 ; 18)(\mathrm{q} 21 ; \mathrm{q} 21)$ associated with MALT-type lymphoma. Leukemia 2002, 16, 1863-1864. [CrossRef]

74. Kubonishi, I.; Sugito, S.; Kobayashi, M.; Asahi, Y.; Tsuchiya, T.; Yamashiro, T.; Miyoshi, I. A unique chromosome translocation, $\mathrm{t}(11 ; 12 ; 18)(\mathrm{q} 21 ; \mathrm{q} 13 ; \mathrm{q} 21)$ [correction of $\mathrm{t}(11 ; 12 ; 18)(\mathrm{q} 13 ; \mathrm{q} 13 ; \mathrm{q} 12)$ ], in primary lung lymphoma. Cancer Genet. Cytogenet. 1995, 82, 54-56. [CrossRef]

75. Murga Penas, E.M.; Callet-Bauchu, E.; Ye, H.; Hinz, K.; Albert, N.; Copie-Bergman, C.; Gazzo, S.; Berger, F.; Salles, G.; Bokemeyer C.; et al. The translocations $\mathrm{t}(6 ; 18 ; 11)(\mathrm{q} 24 ; \mathrm{q} 21 ; \mathrm{q} 21)$ and $\mathrm{t}(11 ; 14 ; 18)(\mathrm{q} 21 ; \mathrm{q} 32 ; \mathrm{q} 21)$ lead to a fusion of the API2 and MALT1 genes and occur in MALT lymphomas. Haematologica 2007, 92, 405-409. [CrossRef]

76. Alpen, B.; Neubauer, A.; Dierlamm, J.; Marynen, P.; Thiede, C.; Bayerdörffer, E.; Stolte, M. Translocation $\mathrm{t}(11 ; 18)$ absent in early gastric marginal zone B-cell lymphoma of MALT type responding to eradication of Helicobacter pylori infection. Blood 2000, 95, 4014-4015. [CrossRef]

77. Liu, H.; Ye, H.; Ruskone-Fourmestraux, A.; De Jong, D.; Pileri, S.; Thiede, C.; Lavergne, A.; Boot, H.; Caletti, G.; Wündisch, T.; et al. $\mathrm{T}(11 ; 18)$ is a marker for all stage gastric MALT lymphomas that will not respond to $H$. pylori eradication. Gastroenterology 2002, 122, 1286-1294. [CrossRef]

78. Montalban, C.; Santón, A.; Redondo, C.; García-Cosio, M.; Boixeda, D.; Vazquez-Sequeiros, E.; Norman, F.; de Argila, C.M.; Alvarez, I.; Abraira, V.; et al. Long-term persistence of molecular disease after histological remission in low-grade gastric MALT lymphoma treated with $H$. pylori eradication. Lack of association with translocation $\mathrm{t}(11 ; 18)$ : A 10-year updated follow-up of a prospective study. Ann. Oncol. 2005, 16, 1539-1544. [CrossRef]

79. Nakamura, S.; Matsumoto, T.; Nakamura, S.; Jo, Y.; Fujisawa, K.; Suekane, H.; Yao, T.; Tsuneyoshi, M.; Iida, M. Chromosomal translocation $\mathrm{t}(11 ; 18)(\mathrm{q} 21 ; \mathrm{q} 21)$ in gastrointestinal mucosa associated lymphoid tissue lymphoma. J. Clin. Pathol. 2003, 56, 36-42. [CrossRef]

80. Iwano, M.; Okazaki, K.; Uchida, K.; Nakase, H.; Ohana, M.; Matsushima, Y.; Inagaki, H.; Chiba, T. Characteristics of gastric B-cell lymphoma of mucosa-associated lymphoid tissue type involving multiple organs. J. Gastroenterol. 2004, 39, 739-746. [CrossRef]

81. Yeh, K.H.; Kuo, S.H.; Chen, L.T.; Mao, T.L.; Doong, S.L.; Wu, M.S.; Hsu, H.C.; Tzeng, Y.S.; Chen, C.L.; Lin, J.T.; et al. Nuclear expression of BCL10 or nuclear factor kappa B helps predict Helicobacter pylori-independent status of low-grade gastric mucosaassociated lymphoid tissue lymphomas with or without $\mathrm{t}(11 ; 18)(\mathrm{q} 21 ; \mathrm{q} 21)$. Blood 2005, 106, 1037-1041. [CrossRef]

82. Nakamura, S.; Ye, H.; Bacon, C.M.; Goatly, A.; Liu, H.; Banham, A.H.; Ventura, R.; Matsumoto, T.; Iida, M.; Ohji, Y.; et al. Clinical impact of genetic aberrations in gastric MALT lymphoma: A comprehensive analysis using interphase fluorescence in situ hybridisation. Gut 2007, 56, 1358-1363. [CrossRef] [PubMed]

83. Ye, H.; Liu, H.; Attygalle, A.; Wotherspoon, A.C.; Nicholson, A.G.; Charlotte, F.; Leblond, V.; Speight, P.; Goodlad, J.; LavergneSlove, A.; et al. Variable frequencies of $\mathrm{t}(11 ; 18)(\mathrm{q} 21 ; \mathrm{q} 21)$ in MALT lymphomas of different sites: Significant association with CagA strains of $H$. pylori in gastric MALT lymphoma. Blood 2003, 102, 1012-1018. [CrossRef] [PubMed]

84. Kuo, S.H.; Chen, L.T.; Yeh, K.H.; Wu, M.S.; Hsu, H.C.; Yeh, P.Y.; Mao, T.L.; Chen, C.L.; Doong, S.L.; Lin, J.T.; et al. Nuclear expression of BCL10 or nuclear factor kappa B predicts Helicobacter pylori-independent status of early-stage, high-grade gastric mucosa-associated lymphoid tissue lymphomas. J. Clin. Oncol. 2004, 22, 3491-3497. [CrossRef] [PubMed]

85. Ye, H.; Gong, L.; Liu, H.; Ruskone-Fourmestraux, A.; De Jong, D.; Pileri, S.; Thiede, C.; Lavergne, A.; Boot, H.; Caletti, G.; et al. Strong BCL10 nuclear expression identifies gastric MALT lymphomas that do not respond to H. pylori eradication. Gut 2006, 55, 137-139. [CrossRef] [PubMed]

86. Toyoda, K.; Maeshima, A.M.; Nomoto, J.; Suzuki, T.; Yuda, S.; Yamauchi, N.; Taniguchi, H.; Makita, S.; Fukuhara, S.; Munakata, W.; et al. Mucosa-associated lymphoid tissue lymphoma with t(11;18)(q21;q21) translocation: Long-term follow-up results. Ann. Hematol. 2019, 98, 1675-1687. [CrossRef] [PubMed]

87. Dong, G.; Liu, C.; Ye, H.; Gong, L.; Zheng, J.; Li, M.; Huang, X.; Huang, X.; Huang, Y.; Shi, Y.; et al. BCL10 nuclear expression and $\mathrm{t}(11 ; 18)(\mathrm{q} 21 ; \mathrm{q} 21)$ indicate nonresponsiveness to Helicobacter pylori eradication of Chinese primary gastric MALT lymphoma. Int. J. Hematol. 2009, 88, 516-523. [CrossRef] [PubMed]

88. Salar, A.; Bellosillo, B.B.; Serrano, S.; Besses, C. Persistent residual disease in $\mathrm{t}(11 ; 18)(\mathrm{q} 21 ; \mathrm{q} 21)$ positive gastric mucosa-associated lymphoid tissue lymphoma treated with chemotherapy or rituximab. J. Clin. Oncol. 2005, 23, 7361-7362. [CrossRef]

89. Lévy, M.; Copie-Bergman, C.; Gameiro, C.; Chaumette, M.T.; Delfau-Larue, M.H.; Haioun, C.; Charachon, A.; Hemery, F.; Gaulard, P.; Leroy, K.; et al. Prognostic value of translocation $t(11 ; 18)$ in tumoral response of low-grade gastric lymphoma of mucosa-associated lymphoid tissue type to oral chemotherapy. J. Clin. Oncol. 2005, 23, 5061-5066. [CrossRef]

90. Martinelli, G.; Laszlo, D.; Ferreri, A.J.M.M.; Pruneri, G.; Ponzoni, M.; Conconi, A.; Crosta, C.; Pedrinis, E.; Bertoni, F.; Calabrese, L.; et al. Clinical activity of rituximab in gastric marginal zone non-Hodgkin's lymphoma resistant to or not eligible for anti-Helicobacter pylori therapy. J. Clin. Oncol. 2005, 23, 1979-1983. [CrossRef]

91. Lévy, M.; Copie-Bergman, C.; Molinier-Frenkel, V.; Riou, A.; Haioun, C.; Gaulard, P.; Delfau-Larue, M.-H.H.; Sobhani, I.; Leroy, K.; Delchier, J.-C.C. Treatment of $\mathrm{t}(11 ; 18)$-positive gastric mucosa-associated lymphoid tissue lymphoma with rituximab and chlorambucil: Clinical, histological, and molecular follow-up. Leuk. Lymphoma 2010, 51, 284-290. [CrossRef] 
92. Salar, A.; Domingo-Domenech, E.; Panizo, C.; Nicolás, C.; Bargay, J.; Muntañola, A.; Canales, M.; Bello, J.L.; Sancho, J.M.; Tomás, J.F.; et al. First-line response-adapted treatment with the combination of bendamustine and rituximab in patients with mucosa-associated lymphoid tissue lymphoma (MALT2008-01): A multicentre, single-arm, phase 2 trial. Lancet Haematol. 2014, 1 , e104-e111. [CrossRef]

93. Ruskone-Fourmestraux, A.; Fischbach, W.; Aleman, B.M.P.; Boot, H.; Du, M.Q.; Megraud, F.; Montalban, C.; Raderer, M.; Savio, A.; Wotherspoon, A.; et al. EGILS consensus report. Gastric extranodal marginal zone B-cell lymphoma of MALT. Gut 2011, 60, 747-758. [CrossRef]

94. Zucca, E.; Arcaini, L.; Buske, C.; Johnson, P.W.; Ponzoni, M.; Raderer, M.; Ricardi, U.; Salar, A.; Stamatopoulos, K.; Thieblemont, C.; et al. Marginal zone lymphomas: ESMO Clinical Practice Guidelines for diagnosis, treatment and follow-up. Ann. Oncol. 2020, 31, 17-29. [CrossRef]

95. Kobayashi, Y.; Nakata, M.; Maekawa, M.; Takahashi, M.; Fujii, H.; Matsuno, Y.; Mitsuhiro, F.; Hiroyuki, O.; Daizo, S.; Takeaki, T.; et al. Detection of $\mathrm{t}(11 ; 18)$ in MALT-type lymphoma with dual-color fluorescence in situ hybridization and reverse transcriptasepolymerase chain reaction analysis. Diagn. Mol. Pathol. 2001, 10, 207-213. [CrossRef]

96. Fecteau, J.F.; Néron, S. CD40 stimulation of human peripheral B lymphocytes: Distinct response from naive and memory cells. J. Immunol. 2003, 171, 4621-4629. [CrossRef]

97. Chen, J.; Chen, Z.J. Signaling to NF-kappaB: Regulation by ubiquitination. Cold Spring Harb. Perspect. Biol. 2010, 2 , a003350.

98. Du, M.-Q. MALT lymphoma: Genetic abnormalities, immunological stimulation and molecular mechanism. Best Pract. Res. Clin. Haematol. 2017, 30, 13-23. [CrossRef]

99. Takada, S.; Yoshino, T.; Taniwaki, M.; Nakamura, N.; Nakamine, H.; Oshima, K.; Sadahira, Y.; Inagaki, H.; Oshima, K.; Tadaatsu, A. Involvement of the chromosomal translocation $t(11 ; 18)$ in some mucosa-associated lymphoid tissue lymphomas and diffuse large B-cell lymphomas of the ocular adnexa: Evidence from multiplex reverse transcriptase-polymerase chain reaction and fluorescence in situ hybridization on using formalin-fixed, paraffin-embedded specimens. Mod. Pathol. 2003, 16, 445-452 [PubMed]

100. Streubel, B.; Lamprecht, A.; Dierlamm, J.; Cerroni, L.; Stolte, M.; Ott, G.; Raderer, M.; Chott, A. T(14;18)(q32;q21) involving IGH and MALT1 is a frequent chromosomal aberration in MALT lymphoma. Blood 2003, 101, 2335-2339. [CrossRef]

101. Thome, M. CARMA1, BCL-10 and MALT1 in lymphocyte development and activation. Nat. Rev. Immunol. 2004, 4, 348-359. [CrossRef] [PubMed]

102. Ye, H.; Gong, L.; Liu, H.; Hamoudi, R.A.; Shirali, S.; Ho, L.; Chott, A.; Streubel, B.; Siebert, R.; Gesk, S.; et al. MALT lymphoma with $\mathrm{t}(14 ; 18)(\mathrm{q} 32 ; \mathrm{q} 21) /$ IGH-MALT1 is characterized by strong cytoplasmic MALT1 and BCL10 expression. J. Pathol. 2005, 205, 293-301. [CrossRef]

103. Achuthan, R.; Bell, S.M.; Carr, I.M.; Leek, J.P.; Roberts, P.; Horgan, K.; Markham, A.F.; Selby, P.J.; MacLennan, K.A. BCL10 in malignant lymphomas-An evaluation using fluorescence in situ hybridization. J. Pathol. 2002, 196, 59-66. [CrossRef] [PubMed]

104. Coornaert, B.; Baens, M.; Heyninck, K.; Bekaert, T.; Haegman, M.; Staal, J.; Sun, L.; Chen, Z.J.; Marynen, P.; Beyaert, R. T cell antigen receptor stimulation induces MALT1 paracaspase-Mediated cleavage of the NF- $\mathrm{KB}$ inhibitor A20. Nat. Immunol. 2008, 9 , 263-271. [CrossRef]

105. Düwel, M.; Welteke, V.; Oeckinghaus, A.; Baens, M.; Kloo, B.; Ferch, U.; Darnay, B.G.; Ruland, J.; Marynen, P.; Krappmann, D. A20 negatively regulates T cell receptor signaling to NF-kappaB by cleaving Malt1 ubiquitin chains. J. Immunol. 2009, 182, 7718-7728. [CrossRef] [PubMed]

106. Kirchhofer, D.; Vucic, D. Protease activity of MALT1: A mystery unravelled. Biochem. J. 2012, 444, e3-e5. [CrossRef]

107. Hailfinger, S.; Nogai, H.; Pelzer, C.; Jaworski, M.; Cabalzar, K.; Charton, J.E.; Guzzardi, M.; Décaillet, C.; Grau, M.; Dörken, B.; et al. Malt1-dependent RelB cleavage promotes canonical NF-kappaB activation in lymphocytes and lymphoma cell lines. Proc. Natl. Acad. Sci. USA 2011, 108, 14596-14601. [CrossRef] [PubMed]

108. Tusche, M.W.; Ward, L.A.; Vu, F.; McCarthy, D.; Quintela-Fandino, M.; Ruland, J.; Gommerman, J.L.; Mak, T.W. Differential requirement of MALT1 for BAFF-induced outcomes in B cell subsets. J. Exp. Med. 2009, 206, 2671. [CrossRef]

109. Zhang, S.; Wei, M.; Liang, Q.; Johnson, D.; Dow, N.; Nelson, A.; Aguilera, N.; Auerbach, A.; Wang, G. The t(14;18)(q32;q21)/IGHMALT1 translocation in gastrointestinal extranodal marginal zone lymphoma of mucosa-associated lymphoid tissue (MALT lymphoma). Histopathology 2014, 64, 791-798. [CrossRef]

110. Tanimoto, K.; Sekiguchi, N.; Yokota, Y.; Kaneko, A.; Watanabe, T.; Maeshima, A.M.; Matsuno, Y.; Harada, M.; Tobinai, K.; Kobayashi, Y. Fluorescence in situhybridization (FISH) analysis of primary ocular adnexal MALT lymphoma. BMC Cancer 2006, 6, 249. [CrossRef]

111. Wongchaowart, N.T.; Kim, B.; Hsi, E.D.; Swerdlow, S.H.; Tubbs, R.R.; Cook, J.R. t(14;18)(q32;q21) involving IGH and MALT1 is uncommon in cutaneous MALT lymphomas and primary cutaneous diffuse large B-cell lymphomas. J. Cutan. Pathol. 2006, 33, 286-292. [CrossRef]

112. Garcia, M.; Konoplev, S.; Morosan, C.; Abruzzo, L.V.; Bueso-Ramos, C.E.; Medeiros, L.J. MALT lymphoma involving the kidney: A report of 10 cases and review of the literature. Am. J. Clin. Pathol. 2007, 128, 464-473. [CrossRef] [PubMed]

113. Bhagavathi, S.; Greiner, T.C.; Kazmi, S.A.; Fu, K.; Sanger, W.G.; Chan, W.C. Extranodal marginal zone lymphoma of the dura mater with IgH/MALT1 translocation and review of literature. J. Hematop. 2008, 1, 131-137. [CrossRef] [PubMed] 
114. Kuper-Hommel, M.J.J.; Schreuder, M.I.; Gemmink, A.H.; van Krieken, J.H.J.M. T(14;18)(q32;q21) involving MALT1 and IGH genes occurs in extranodal diffuse large B-cell lymphomas of the breast and testis. Mod. Pathol. 2013, 26, 421-427. [CrossRef] [PubMed]

115. Cook, J.R.; Sherer, M.; Craig, F.E.; Shekhter-Levin, S.; Swerdlow, S.H. T(14;18)(q32;q21) involving MALT1 and IGH genes in an extranodal diffuse large B-cell lymphoma. Hum. Pathol. 2003, 34, 1212-1215. [CrossRef] [PubMed]

116. Maes, B.; Demunter, A.; Peeters, B.; De Wolf-Peeters, C. BCL10 mutation does not represent an important pathogenic mechanism in gastric MALT-type lymphoma, and the presence of the API2-MLT fusion is associated with aberrant nuclear BCL10 expression. Blood 2002, 99, 1398-1404. [CrossRef]

117. Ye, H.; Dogan, A.; Karran, L.; Willis, T.G.; Chen, L.; Wlodarska, I.; Dyer, M.J.; Isaacson, P.G.; Du, M.Q. BCL10 expression in normal and neoplastic lymphoid tissue. Nuclear localization in MALT lymphoma. Am. J. Pathol. 2000, 157, 1147-1154. [CrossRef]

118. Streubel, B.; Vinatzer, U.; Lamprecht, A.; Raderer, M.; Chott, A. T(3;14)(p14.1;q32) involving IGH and FOXP1 is a novel recurrent chromosomal aberration in MALT lymphoma. Leukemia 2005, 19, 652-658. [CrossRef]

119. Wlodarska, I.; Veyt, E.; De Paepe, P.; Vandenberghe, P.; Nooijen, P.; Theate, I.; Michaux, L.; Sagaert, X.; Marynen, P.; Hagemeijer, A.; et al. FOXP1, a gene highly expressed in a subset of diffuse large B-cell lymphoma, is recurrently targeted by genomic aberrations. Leukemia 2005, 19, 1299-1305. [CrossRef]

120. Fenton, J.A.L.; Schuuring, E.; Barrans, S.L.; Banham, A.H.; Rollinson, S.J.; Morgan, G.J.; Jack, A.S.; van Krieken, J.H.J.M.; Kluin, P.M. t(3;14)(p14;q32) Results in aberrant expression of FOXP1 in a case of diffuse large B-cell lymphoma. Genes Chromosom. Cancer 2006, 45, 164-168. [CrossRef]

121. Vinatzer, U.; Gollinger, M.; Müllauer, L.; Raderer, M.; Chott, A.; Streubel, B. Mucosa-associated lymphoid tissue lymphoma: Novel translocations including rearrangements of ODZ2, JMJD2C, and CNN3. Clin. Cancer Res. 2008, 14, 6426-6431. [CrossRef]

122. Ansell, S.M.; Akasaka, T.; McPhail, E.; Manske, M.; Braggio, E.; Price-Troska, T.; Ziesmer, S.; Secreto, F.; Fonseca, R.; Gupta, M.; et al. $\mathrm{t}(\mathrm{X} ; 14)(\mathrm{p} 11 ; \mathrm{q} 32)$ in MALT lymphoma involving GPR34 reveals a role for GPR34 in tumor cell growth. Blood 2012, 120, 3949-3957. [CrossRef] [PubMed]

123. Baens, M.; Ferreiro, J.F.; Tousseyn, T.; Urbankova, H.; Michaux, L.; de Leval, L.; Dierickx, D.; Wolter, P.; Sagaert, X.; Vandenberghe, P.; et al. $\mathrm{t}(\mathrm{X} ; 14)(\mathrm{p} 11.4 ; \mathrm{q} 32.33)$ is recurrent in marginal zone lymphoma and up-regulates GPR34. Haematologica 2012, 97, 184-188. [CrossRef] [PubMed]

124. Chuang, S.; Liu, H.; Ye, H.; Martín-Subero, J.I.; Siebert, R.; Huang, W. Pulmonary mucosa-associated lymphoid tissue lymphoma with strong nuclear B-cell CLL/lymphoma 10 (BCL10) expression and novel translocation $\mathrm{t}(1 ; 2)(\mathrm{p} 22 ; \mathrm{p} 12) / \mathrm{immunoglobulin} \mathrm{K}$ chain-BCL10. J. Clin. Pathol. 2007, 60, 727. [CrossRef] [PubMed]

125. Van Keimpema, M.; Grüneberg, L.J.; Mokry, M.; Van Boxtel, R.; Van Zelm, M.C.; Coffer, P.; Pals, S.T.; Spaargaren, M. The forkhead transcription factor FOXP1 represses human plasma cell differentiation. Blood 2015, 126, 2098-2109. [CrossRef] [PubMed]

126. van Keimpema, M.; Grüneberg, L.J.; Mokry, M.; van Boxtel, R.; Koster, J.; Coffer, P.J.; Pals, S.T.; Spaargaren, M. FOXP1 directly represses transcription of proapoptotic genes and cooperates with NF- $\mathrm{B}$ to promote survival of human B cells. Blood 2014, 124, 3431. [CrossRef] [PubMed]

127. Sasaki, Y.; Shiozawa, E.; Watanabe, N.; Homma, M.; Noh, J.Y.; Ito, K.; Takimoto, M.; Yamochi-Onizuka, T. t(3;14)(p14.1;q32)/FOXP1IGH translocation in thyroid extranodal marginal zone lymphoma of mucosa-associated lymphoid tissue (MALT lymphoma). Leuk. Res. 2020, 95, 106399. [CrossRef]

128. Wu, F.; Watanabe, N.; Tzioni, M.-M.; Akarca, A.; Zhang, C.; Li, Y.; Chen, Z.; Cucco, F.; Carmell, N.; Noh, J.Y.; et al. Thyroid MALT lymphoma: Self-harm to gain potential T-cell help. Leukemia 2021, 35, 3497-3508. [CrossRef]

129. Wotherspoon, A.C.; Pan, L.; Diss, T.C.; Isaacson, P.G. Cytogenetic study of B-cell lymphoma of mucosa-associated lymphoid tissue. Cancer Genet. Cytogenet. 1992, 58, 35-38. [CrossRef]

130. Whang-Peng, J.; Knutsen, T.; Jaffe, E.; Raffeld, M.; Zhao, W.P.; Duffey, P.; Longo, D.L. Cytogenetic study of two cases with lymphoma of mucosa-associated lymphoid tissue. Cancer Genet. Cytogenet. 1994, 77, 74-80. [CrossRef]

131. Dierlamm, J.; Michaux, L.; Wlodarska, I.; Pittaluga, S.; Zeller, W.; Stul, M.; Criel, A.; Thomas, J.; Boogaerts, M.; Delaere, P.; et al Trisomy 3 in marginal zone B-cell lymphoma: A study based on cytogenetic analysis and fluorescence in situ hybridization. Br. J. Haematol. 1996, 93, 242-249. [CrossRef]

132. Taji, S.; Nomura, K.; Matsumoto, Y.; Sakabe, H.; Yoshida, N.; Mitsufiji, S.; Nishida, K.; Horiike, S.; Nakamura, S.; Morita, M.; et al Trisomy 3 may predict a poor response of gastric MALT lymphoma to Helicobacter pylori eradication therapy. World J. Gastroenterol. 2005, 11, 89-93. [CrossRef] [PubMed]

133. Ott, G.; Katzenberger, T.; Greiner, A.; Kalla, J.; Rosenwald, A.; Heinrich, U.; Ott, M.M.; Müller-Hermelink, H.K. The $\mathrm{t}(11 ; 18)(\mathrm{q} 21 ; \mathrm{q} 21)$ Chromosome Translocation Is a Frequent and Specific Aberration in Low-Grade but not High-Grade Malignant Non-Hodgkin's Lymphomas of the Mucosa-associated Lymphoid Tissue (MALT-) Type. AACR 1997, 57, $3944-3948$.

134. Clark, H.M.; Jones, D.B.; Wright, D.H. Cytogenetic and molecular studies of $t(14 ; 18)$ and $t(14 ; 19)$ in nodal and extranodal B-cell lymphoma. J. Pathol. 1992, 166, 129-137. [CrossRef] [PubMed]

135. Wotherspoon, A.C.; Finn, T.M.; Isaacson, P.G. Trisomy 3 in Low-Grade B-Cell Lymphomas of Mucosa-Associated Lymphoid Tissue. Blood 1995, 85, 2000-2004. [CrossRef] [PubMed]

136. Ott, G.; Kalla, J.; Steinhoff, A.; Rosenwald, A.; Katzenberger, T.; Roblick, U.; Ott, M.M.; Müller-Hermelink, H.K. Trisomy 3 Is Not a Common Feature in Malignant Lymphomas of Mucosa-Associated Lymphoid Tissue Type. Am. J. Pathol. 1998, 153, 689. [CrossRef] 
137. Blanco, R.; Lyda, M.; Davis, B.; Kraus, M.; Fenoglio-Preiser, C. Trisomy 3 in gastric lymphomas of extranodal marginal zone B-cell (mucosa-associated lymphoid tissue) origin demonstrated by FISH in intact paraffin tissue sections. Hum. Pathol. 1999, 30, 706-711. [CrossRef]

138. Zhang, Y.; Cheung, A.N.; Chan, A.C.; Shen, D.H.; Xu, W.S.; Chung, L.P.; Ho, F.C. Detection of trisomy 3 in primary gastric B-cell lymphoma by using chromosome in situ hybridization on paraffin sections. Am. J. Clin. Pathol. 1998, 110, 347-353. [CrossRef]

139. Brynes, R.K.; Almaguer, P.D.; Leathery, K.E.; McCourty, A.; Arber, D.A.; Medeiros, L.J.; Nathwani, B.N. Numerical cytogenetic abnormalities of chromosomes 3, 7, and 12 in marginal zone B-cell lymphomas. Mod. Pathol. 1996, 9, 995-1000. [PubMed]

140. Krugmann, J.; Tzankov, A.; Dirnhofer, S.; Fend, F.; Wolf, D.; Siebert, R.; Probst, P.; Erdel, M. Complete or partial trisomy 3 in gastro-intestinal MALT lymphomas co-occurs with aberrations at 18q21 and correlates with advanced disease stage: A study on 25 cases. World J. Gastroenterol. 2005, 11, 7384. [CrossRef] [PubMed]

141. Dierlamm, J.; Rosenberg, C.; Stul, M.; Pittaluga, S.; Wlodarska, I.; Michaux, L.; Dehaen, M.; Verhoef, G.; Thomas, J.; De Kelver W.; et al. Characteristic pattern of chromosomal gains and losses in marginal zone B cell lymphoma detected by comparative genomic hybridization. Leukemia 1997, 11, 747-758. [CrossRef]

142. Rinaldi, A.; Mian, M.; Chigrinova, E.; Arcaini, L.; Bhagat, G.; Novak, U.; Rancoita, P.M.V.; de Campos, C.P.; Forconi, F.; Gascoyne, R.D.; et al. Genome-wide DNA profiling of marginal zone lymphomas identifies subtype-specific lesions with an impact on the clinical outcome. Blood 2011, 117, 1595-1604. [CrossRef]

143. Dierlamm, J.; Wlodarska, I.; Michaux, L.; Stefanova, M.; Hinz, K.; Van Den Berghe, H.; Hagemeijer, A.; Hossfeld, D.K. Genetic abnormalities in marginal zone b-cell lymphoma. Hematol. Oncol. 2000, 18, 1-13. [CrossRef]

144. Deutsch, A.J.A.; Aigelsreiter, A.; Steinbauer, E.; Fruhwirth, M.; Kerl, H.; Beham-Schmid, C.; Schaider, H.; Neumeister, P. Distinct signatures of B-cell homeostatic and activation-dependent chemokine receptors in the development and progression of extragastric MALT lymphomas. J. Pathol. 2008, 215, 431-444. [CrossRef] [PubMed]

145. Cascione, L.; Rinaldi, A.; Bruscaggin, A.; Tarantelli, C.; Arribas, A.J.; Kwee, I.; Pecciarini, L.; Mensah, A.A.; Spina, V.; Chung, E.Y.L.; et al. Novel insights into the genetics and epigenetics of MALT lymphoma unveiled by next generation sequencing analyses. Haematologica 2019, 104, E558-E561. [CrossRef]

146. Remstein, E.D.; Dogan, A.; Einerson, R.R.; Paternoster, S.F.; Fink, S.R.; Law, M.; Gordon, W.; Kurtin, P.J. The incidence and anatomic site specificity of chromosomal translocations in primary extranodal marginal zone B-cell lymphoma of mucosa-associated lymphoid tissue (MALT lymphoma) in North America. Am. J. Surg. Pathol. 2006, 30, 1546-1553. [CrossRef] [PubMed]

147. Joao, C.; Farinha, P.; Da Silva, M.G.; Martins, C.; Crespo, M.; Cabecadas, J. Cytogenetic abnormalities in MALT lymphomas and their precursor lesions from different organs. A fluorescence in situ hybridization (FISH) study. Histopathology 2007, 50, 217-224. [CrossRef]

148. Dierlamm, J.; Pittaluga, S.; Wlodarska, I.; Stul, M.; Thomas, J.; Boogaerts, M.; Michaux, L.; Driessen, A.; Mecucci, C.; Cassiman, J. Marginal Zone B-Cell Lymphomas of Different Sites Share Similar Cytogenetic and Morphologic Features. Blood 1996, 87, $299-307$. [CrossRef]

149. Du, M.; Peng, H.; Singh, N.; Isaacson, P.G.; Pan, L. The Accumulation of p53 Abnormalities Is Associated With Progression of Mucosa-Associated Lymphoid Tissue Lymphoma. Blood 1995, 86, 4587-4593. [CrossRef] [PubMed]

150. Peng, H.; Chen, G.; Du, M.; Singh, N.; Isaacson, P.G.; Pan, L. Replication error phenotype and p53 gene mutation in lymphomas of mucosa-associated lymphoid tissue. Am. J. Pathol. 1996, 148, 643.

151. Rødahl, E.; Lybæk, H.; Arnes, J.; Ness, G.O. Chromosomal imbalances in some benign orbital tumours. Acta Ophthalmol. Scand. 2005, 83, 385-391. [CrossRef]

152. Matteucci, C.; Galieni, P.; Leoncini, L.; Lazzi, S.; Lauria, F.; Polito, E.; Martelli, M.; Mecucci, C. Typical genomic imbalances in primary MALT lymphoma of the orbit. J. Pathol. 2003, 200, 656-660. [CrossRef] [PubMed]

153. Chanudet, E.; Ye, H.; Ferry, J.; Bacon, C.; Adam, P.; Müller-Hermelink, H.; Radford, J.; Pileri, S.; Ichimura, K.; Collins, V.; et al. A20 deletion is associated with copy number gain at the TNFA/B/C locus and occurs preferentially in translocation-negative MALT lymphoma of the ocular adnexa and salivary glands. J. Pathol. 2009, 217, 420-430. [CrossRef] [PubMed]

154. Kim, W.S.; Honma, K.; Karnan, S.; Tagawa, H.; Kim, Y.D.; Oh, Y.L.; Seto, M.; Ko, Y.H. Genome-wide array-based comparative genomic hybridization of ocular marginal zone B cell lymphoma: Comparison with pulmonary and nodal marginal zone B cell lymphoma. Genes Chromosomes Cancer 2007, 46, 776-783. [CrossRef]

155. Honma, K.; Tsuzuki, S.; Nakagawa, M.; Karnan, S.; Aizawa, Y.; Kim, W.S.; Kim, Y.-D.; Ko, Y.-H.; Seto, M. TNFAIP3 is the target gene of chromosome band 6q23.3-q24.1 loss in ocular adnexal marginal zone B cell lymphoma. Genes Chromosomes Cancer 2008, 47, 1-7. [CrossRef]

156. Honma, K.; Tsuzuki, S.; Nakagawa, M.; Tagawa, H.; Nakamura, S.; Morishima, Y.; Seto, M. TNFAIP3/A20 functions as a novel tumor suppressor gene in several subtypes of non-Hodgkin lymphomas. Blood 2009, 114, 2467-2475. [CrossRef]

157. Chanudet, E.; Huang, Y.; Ichimura, K.; Dong, G.; Hamoudi, R.A.; Radford, J.; Wotherspoon, A.C.; Isaacson, P.G.; Ferry, J.; Du, M.-Q. A20 is targeted by promoter methylation, deletion and inactivating mutation in MALT lymphoma. Leukemia 2010, 24, 483-487. [CrossRef] [PubMed]

158. Catrysse, L.; Vereecke, L.; Beyaert, R.; van Loo, G. A20 in inflammation and autoimmunity. Trends Immunol. 2014, 35, 22-31. [CrossRef] 
159. Moody, S.; Thompson, J.S.; Chuang, S.S.; Liu, H.; Raderer, M.; Vassiliou, G.; Wlodarska, I.; Wu, F.; Cogliatti, S.; Robson, A.; et al. Novel GPR34 and CCR6 mutation and distinct genetic profiles in MALT lymphomas of different sites. Haematologica 2018, 103, 1329-1336. [CrossRef]

160. Johansson, P.; Klein-Hitpass, L.; Grabellus, F.; Arnold, G.; Klapper, W.; Pförtner, R.; Dührsen, U.; Eckstein, A.; Dürig, J.; Küppers, R. Recurrent mutations in NF-kB pathway components, KMT2D, and NOTCH1/2 in ocular adnexal MALT-type marginal zone lymphomas. Oncotarget 2016, 7, 62627-62639. [CrossRef]

161. Jung, H.; Yoo, H.Y.; Lee, S.H.; Shin, S.; Kim, S.C.; Lee, S.; Joung, J.-G.; Nam, J.-Y.; Ryu, D.; Yun, J.W.; et al. The mutational landscape of ocular marginal zone lymphoma identifies frequent alterations in TNFAIP3 followed by mutations in TBL1XR1 and CREBBP. Oncotarget 2017, 8, 17038-17049. [CrossRef]

162. Cani, A.K.; Soliman, M.; Hovelson, D.H.; Liu, C.-J.; McDaniel, A.S.; Haller, M.J.; Bratley, J.; Rahrig, S.; Li, Q.; Briceño, C.A.; et al. Comprehensive Genomic Profiling of Orbital and Ocular Adnexal Lymphomas Identifies Frequent Alterations in MYD88 and Chromatin Modifiers: New Routes to Targeted Therapies. Mod. Pathol. 2016, 29, 685. [CrossRef]

163. Behdad, A.; Zhou, X.Y.; Gao, J.; Raparia, K.; Dittman, D.; Green, S.J.; Qi, C.; Betz, B.; Bryar, P.; Chen, Q.; et al. High Frequency of MYD88 L265P Mutation in Primary Ocular Adnexal Marginal Zone Lymphoma and Its Clinicopathologic Correlation: A Study From a Single Institution. Arch. Pathol. Lab. Med. 2019, 143, 483-493. [CrossRef] [PubMed]

164. Li, Z.M.; Rinaldi, A.; Cavalli, A.; Mensah, A.A.; Ponzoni, M.; Gascoyne, R.D.; Bhagat, G.; Zucca, E.; Bertoni, F. MYD88 somatic mutations in MALT lymphomas. Br. J. Haematol. 2012, 158, 662-664. [CrossRef] [PubMed]

165. Yan, Q.; Wang, M.; Moody, S.; Xue, X.; Huang, Y.; Bi, Y.; Du, M.Q. Distinct involvement of NF- $\kappa B$ regulators by somatic mutation in ocular adnexal malt lymphoma. Br. J. Haematol. 2013, 160, 851-854. [CrossRef] [PubMed]

166. Ngo, V.N.; Young, R.M.; Schmitz, R.; Jhavar, S.; Xiao, W.; Lim, K.H.; Kohlhammer, H.; Xu, W.; Yang, Y.; Zhao, H.; et al Oncogenically active MYD88 mutations in human lymphoma. Nature 2011, 470, 115-121. [CrossRef]

167. Bi, Y.; Zeng, N.; Chanudet, E.; Huang, Y.; Hamoudi, R.A.; Liu, H.; Dong, G.; Watkins, A.J.; Ley, S.C.; Zou, L.; et al. A20 inactivation in ocular adnexal MALT lymphoma. Haematologica 2012, 97, 926-930. [CrossRef]

168. Vela, V.; Juskevicius, D.; Gerlach, M.M.; Meyer, P.; Graber, A.; Cathomas, G.; Dirnhofer, S.; Tzankov, A. High throughput sequencing reveals high specificity of TNFAIP3 mutations in ocular adnexal marginal zone B-cell lymphomas. Hematol. Oncol. 2020, 38, 284-292. [CrossRef] [PubMed]

169. Ganapathi, K.A.; Jobanputra, V.; Iwamoto, F.; Jain, P.; Chen, J.; Cascione, L.; Nahum, O.; Levy, B.; Xie, Y.; Khattar, P.; et al. The genetic landscape of dural marginal zone lymphomas. Oncotarget 2016, 7, 43052. [CrossRef]

170. Agathangelidis, A.; Xochelli, A.; Stamatopoulos, K. A gene is known by the company it keeps: Enrichment of TNFAIP3 gene aberrations in MALT lymphomas expressing IGHV4-34 antigen receptors. J. Pathol. 2017, 243, 403-406. [CrossRef]

171. Hayden, M.S.; Ghosh, S. Regulation of NF-kB by TNF family cytokines. Semin. Immunol. 2014, 26, 253-266. [CrossRef]

172. Vereecke, L.; Beyaert, R.; van Loo, G. The ubiquitin-editing enzyme A20 (TNFAIP3) is a central regulator of immunopathology. Trends Immunol. 2009, 30, 383-391. [CrossRef]

173. Boone, D.L.; Turer, E.E.; Lee, E.G.; Ahmad, R.C.; Wheeler, M.T.; Tsui, C.; Hurley, P.; Chien, M.; Chai, S.; Hitotsumatsu, O.; et al. The ubiquitin-modifying enzyme A20 is required for termination of Toll-like receptor responses. Nat. Immunol. 2004, 5, 1052-1060. [CrossRef]

174. Thome, M.; Tschopp, J. TCR-induced NF-kappaB activation: A crucial role for Carma1, Bcl10 and MALT1. Trends Immunol. 2003, 24, 419-424. [CrossRef]

175. Shi, J.H.; Sun, S.C. Tumor Necrosis Factor Receptor-Associated Factor Regulation of Nuclear Factor $\kappa B$ and Mitogen-Activated Protein Kinase Pathways. Front. Immunol. 2018, 9, 1849. [CrossRef] [PubMed]

176. Hyeon, J.; Lee, B.; Shin, S.H.; Yoo, H.Y.; Kim, S.J.; Kim, W.S.; Park, W.-Y.; Ko, Y.-H. Targeted deep sequencing of gastric marginal zone lymphoma identified alterations of TRAF3 and TNFAIP3 that were mutually exclusive for MALT1 rearrangement. Mod. Pathol. 2018, 31, 1418-1428. [CrossRef] [PubMed]

177. Pillai, S.; Cariappa, A.; Moran, S.T. Marginal Zone B Cells. Annu. Rev. Immunol. 2005, 23, 161-196. [CrossRef]

178. Pillai, S.; Cariappa, A. The follicular versus marginal zone B lymphocyte cell fate decision. Nat. Rev. Immunol. 2009, 9, 767-777. [CrossRef] [PubMed]

179. Saito, T.; Chiba, S.; Ichikawa, M.; Kunisato, A.; Asai, T.; Shimizu, K.; Yamaguchi, T.; Yamamoto, G.; Seo, S.; Kumano, K.; et al. Notch2 Is Preferentially Expressed in Mature B Cells and Indispensable for Marginal Zone B Lineage Development. Immunity 2003, 18, 675-685. [CrossRef]

180. Hampel, F.; Ehrenberg, S.; Hojer, C.; Draeseke, A.; Marschall-Schröter, G.; Kühn, R.; Mack, B.; Gires, O.; Vahl, C.J.; SchmidtSupprian, M.; et al. CD19-independent instruction of murine marginal zone B-cell development by constitutive Notch2 signaling. Blood 2011, 118, 6321-6331. [CrossRef]

181. Zhang, X.; Shi, Y.; Weng, Y.; Lai, Q.; Luo, T.; Zhao, J.; Ren, G.; Li, W.; Pan, H.; Ke, Y.; et al. The Truncate Mutation of Notch2 Enhances Cell Proliferation through Activating the NF-кB Signal Pathway in the Diffuse Large B-Cell Lymphomas. PLoS ONE 2014, 9, e108747. [CrossRef]

182. Puente, X.S.; Pinyol, M.; Quesada, V.; Conde, L.; Ordonez, G.R.; Villamor, N.; Escaramis, G.; Jares, P.; Bea, S.; Gonzalez-Diaz, M.; et al. Whole-genome sequencing identifies recurrent mutations in chronic lymphocytic leukaemia. Nature 2011, 475, 101-105. [CrossRef] 
183. Arcaini, L.; Rossi, D.; Lucioni, M.; Nicola, M.; Bruscaggin, A.; Fiaccadori, V.; Riboni, R.; Ramponi, A.; Ferretti, V.V.; Cresta, S.; et al. The NOTCH pathway is recurrently mutated in diffuse large B-cell lymphoma associated with hepatitis $\mathrm{C}$ virus infection. Haematologica 2015, 100, 246-252. [CrossRef]

184. Rossi, D.; Trifonov, V.; Fangazio, M.; Bruscaggin, A.; Rasi, S.; Spina, V.; Monti, S.; Vaisitti, T.; Arruga, F.; Famà, R.; et al. The coding genome of splenic marginal zone lymphoma: Activation of NOTCH2 and other pathways regulating marginal zone development. J. Exp. Med. 2012, 209, 1537-1551. [CrossRef]

185. Kiel, M.J.; Velusamy, T.; Betz, B.L.; Zhao, L.; Weigelin, H.G.; Chiang, M.Y.; Huebner-Chan, D.R.; Bailey, N.G.; Yang, D.T.; Bhagat, G.; et al. Whole-genome sequencing identifies recurrent somatic NOTCH2 mutations in splenic marginal zone lymphoma. J. Exp. Med. 2012, 209, 1553-1565. [CrossRef]

186. Karube, K.; Martínez, D.; Royo, C.; Navarro, A.; Pinyol, M.; Cazorla, M.; Castillo, P.; Valera, A.; Carrió, A.; Costa, D.; et al. Recurrent mutations of NOTCH genes in follicular lymphoma identify a distinctive subset of tumours. J. Pathol. 2014, 234, 423-430. [CrossRef]

187. Kuksin, C.A.; Minter, L.M. The Link between Autoimmunity and Lymphoma: Does NOTCH Signaling Play a Contributing Role? Front. Oncol. 2015, 5, 51. [CrossRef] [PubMed]

188. Johansson, P.; Klein-Hitpass, L.; Budeus, B.; Kuhn, M.; Lauber, C.; Seifert, M.; Roeder, I.; Pförtner, R.; Stuschke, M.; Dührsen, U.; et al. Identifying Genetic Lesions in Ocular Adnexal Extranodal Marginal Zone Lymphomas of the MALT Subtype by Whole Genome, Whole Exome and Targeted Sequencing. Cancers 2020, 12, 986. [CrossRef] [PubMed]

189. Kiesewetter, B.; Copie-Bergman, C.; Levy, M.; Wu, F.; Dupuis, J.; Barau, C.; Arcaini, L.; Paulli, M.; Lucioni, M.; Bonometti, A.; et al. Genetic Characterization and Clinical Features of Helicobacter pylori Negative Gastric Mucosa-Associated Lymphoid Tissue Lymphoma. Cancers 2021, 13, 2993. [CrossRef] [PubMed]

190. Zhu, J.; Wei, R.L.; Pi, Y.L.; Guo, Q. Significance of Bcl10 gene mutations in the clinical diagnosis of MALT-type ocular adnexal lymphoma in the Chinese population. Genet. Mol. Res. 2013, 12, 1194-1204. [CrossRef] [PubMed]

191. Shingleton, J.R.; Dave, S.S. TET2 Deficiency Sets the Stage for B-cell Lymphoma. Cancer Discov. 2018, 8, 1515-1517. [CrossRef] [PubMed]

192. Du, M.Q. MALT lymphoma: A paradigm of NF-кB dysregulation. Semin. Cancer Biol. 2016, 39, 49-60. [CrossRef] [PubMed]

193. Wen, S.; Liu, T.; Zhang, H.; Zhou, X.; Jin, H.; Sun, M.; Yun, Z.; Luo, H.; Ni, Z.; Zhao, R.; et al. Whole-Exome Sequencing Reveals New Potential Mutations Genes for Primary Mucosa-Associated Lymphoid Tissue Lymphoma Arising From the Kidney. Front. Oncol. 2021, 10, 609839. [CrossRef]

194. Bartel, D.P. MicroRNAs: Target recognition and regulatory functions. Cell 2009, 136, 215-233. [CrossRef] [PubMed]

195. Fernandez-Mercado, M.; Manterola, L.; Lawrie, C.H. MicroRNAs in Lymphoma: Regulatory Role and Biomarker Potential. Curr. Genomics 2015, 16, 349. [CrossRef] [PubMed]

196. Di Lisio, L.; Martinez, N.; Montes-Moreno, S.; Piris-Villaespesa, M.; Sanchez-Beato, M.; Piris, M.A. The role of miRNAs in the pathogenesis and diagnosis of B-cell lymphomas. Blood 2012, 120, 1782-1790. [CrossRef] [PubMed]

197. Lawrie, C.H. MicroRNAs and lymphomagenesis: A functional review. Br. J. Haematol. 2013, 160, 571-581. [CrossRef]

198. Craig, V.J.; Cogliatti, S.B.; Rehrauer, H.; Wündisch, T.; Müller, A. Epigenetic Silencing of MicroRNA-203 Dysregulates ABL1 Expression and Drives Helicobacter-Associated Gastric Lymphomagenesis. Cancer Res. 2011, 71, 3616-3624. [CrossRef]

199. Zhang, Y.; Liu, A.; Quan, L.; Qu, Y.; Gu, A. Three novel microRNAs based on microRNA signatures for gastric mucosa-associated lymphoid tissue lymphoma. Neoplasma 2018, 65, 339-348. [CrossRef]

200. Saito, Y.; Suzuki, H.; Tsugawa, H.; Imaeda, H.; Matsuzaki, J.; Hirata, K.; Hosoe, N.; Nakamura, M.; Mukai, M.; Saito, H.; et al Overexpression of miR-142-5p and miR-155 in Gastric Mucosa-Associated Lymphoid Tissue (MALT) Lymphoma Resistant to Helicobacter pylori Eradication. PLoS ONE 2012, 7, e47396. [CrossRef]

201. Krützfeldt, J.; Rajewsky, N.; Braich, R.; Rajeev, K.G.; Tuschl, T.; Manoharan, M.; Stoffel, M. Silencing of microRNAs in vivo with "antagomirs". Nature 2005, 438, 685-689. [CrossRef]

202. Babar, I.A.; Cheng, C.J.; Booth, C.J.; Liang, X.; Weidhaas, J.B.; Saltzman, W.M.; Slack, F.J. Nanoparticle-based therapy in an in vivo microRNA-155 (miR-155)-dependent mouse model of lymphoma. Proc. Natl. Acad. Sci. USA 2012, 109, E1695-E1704. [CrossRef]

203. Fernández, C.; Bellosillo, B.; Ferraro, M.; Seoane, A.; Sánchez-González, B.; Pairet, S.; Pons, A.; Barranco, L.; Vela, M.C.; Gimeno, E.; et al. MicroRNAs 142-3p, miR-155 and miR-203 are deregulated in gastric MALT lymphomas compared to chronic gastritis. Cancer Genom. Proteom. 2017, 14, 75-82. [CrossRef]

204. Cai, J.; Liu, X.; Cheng, J.; Li, Y.; Huang, X.; Li, Y.; Ma, X.; Yu, H.; Liu, H.; Wei, R. MicroRNA-200 is commonly repressed in conjunctival MALT lymphoma, and targets cyclin E2. Graefes Arch. Clin. Exp. Ophthalmol. 2012, 250, 523-531. [CrossRef] [PubMed]

205. Park, S.M.; Gaur, A.B.; Lengyel, E.; Peter, M.E. The miR-200 family determines the epithelial phenotype of cancer cells by targeting the E-cadherin repressors ZEB1 and ZEB2. Genes Dev. 2008, 22, 894-907. [CrossRef] [PubMed]

206. Wang, Z.; Gerstein, M.; Snyder, M. RNA-Seq: A revolutionary tool for transcriptomics. Nat. Rev. Genet. 2009, 10, 57. [CrossRef] [PubMed]

207. Chng, W.J.; Remstein, E.D.; Fonseca, R.; Bergsagel, P.L.; Vrana, J.A.; Kurtin, P.J.; Dogan, A. Gene expression profiling of pulmonary mucosa-associated lymphoid tissue lymphoma identifies new biologic insights with potential diagnostic and therapeutic applications. Blood 2009, 113, 635-645. [CrossRef] 
208. Hamoudi, R.A.; Appert, A.; Ye, H.; Ruskone-Fourmestraux, A.; Streubel, B.; Chott, A.; Raderer, M.; Gong, L.; Wlodarska, I.; De Wolf-Peeters, C. Differential expression of NF-kappaB target genes in MALT lymphoma with and without chromosome translocation: Insights into molecular mechanism. Leukemia 2010, 24, 1487-1497. [CrossRef]

209. Zou, Q.; Zhang, H.; Meng, F.; He, L.; Zhang, J.; Xiao, D. Proteomic and transcriptomic studies of BGC823 cells stimulated with Helicobacter pylori isolates from gastric MALT lymphoma. PLoS ONE 2020, 15, e0238379. [CrossRef]

210. Zhang, J.; Wei, J.; Wang, Z.; Feng, Y.; Wei, Z.; Hou, X.; Xu, J.; He, Y.; Yang, D. Transcriptome hallmarks in Helicobacter pylori infection influence gastric cancer and MALT lymphoma. Epigenomics 2020, 12, 661-671. [CrossRef] [PubMed]

211. Thomas, P.B.; Jeffery, P.; Gahete, M.D.; Whiteside, E.; Walpole, C.; Maugham, M.; Jovanovic, L.; Gunter, J.; Williams, E.; Nelson, C.; et al. The long non-coding RNA GHSROS reprograms prostate cancer cell lines toward a more aggressive phenotype. PeerJ 2021, 9, e10280. [CrossRef]

212. Lue, J.K.; Amengual, J.E.; O'Connor, O.A. Epigenetics and Lymphoma: Can We Use Epigenetics to Prime or Reset Chemoresistant Lymphoma Programs? Curr. Oncol. Rep. 2015, 17, 40. [CrossRef] [PubMed]

213. Yang, H.; Green, M.R. Harnessing lymphoma epigenetics to improve therapies. Blood 2020, 136, 2386-2391. [CrossRef] [PubMed]

214. Mondello, P.; Tadros, S.; Teater, M.; Fontan, L.; Chang, A.Y.; Jain, N.; Yang, H.; Singh, S.; Ying, H.-Y.; Chu, C.-S. Selective inhibition of HDAC3 targets synthetic vulnerabilities and activates immune surveillance in lymphoma. AACR 2020, 10, 440-459. [CrossRef] [PubMed]

215. Fung, M.K.L.; Au, W.Y.; Liang, R.; Srivastava, G.; Kwong, Y.L. Aberrant promoter methylation in gastric lymphomas. Haematologica 2003, 88, 231-232. [CrossRef]

216. Rossi, D.; Capello, D.; Gloghini, A.; Franceschetti, S.; Paulli, M.; Bhatia, K.; Saglio, G.; Vitolo, U.; Pileri, S.A.; Esteller, M.; et al. Aberrant promoter methylation of multiple genes throughout the clinico-pathologic spectrum of B-cell neoplasia. Haematologica 2004, 89, 154-164.

217. Takino, H.; Okabe, M.; Li, C.; Ohshima, K.; Yoshino, T.; Nakamura, S.; Ueda, R.; Eimoto, T.; Inagaki, H. p16/INK4a gene methylation is a frequent finding in pulmonary MALT lymphomas at diagnosis. Mod. Pathol. 2005, 18, 1187-1192. [CrossRef]

218. Dugge, R.; Wagener, R.; Möller, P.; Barth, T.F.E. Genome-wide DNA methylation analysis along the progression of gastric marginal zone B-cell lymphoma of mucosa-associated lymphoid tissue (MALT) type. Br. J. Haematol. 2021, 193, 369-374. [CrossRef]

219. Deaton, A.M.; Bird, A. CpG islands and the regulation of transcription. Genes Dev. 2011, 25, 1010-1022. [CrossRef]

220. Davis, A.R.; Stone, S.L.; Oran, A.R.; Sussman, R.T.; Bhattacharyya, S.; Morrissette, J.J.; Bagg, A. Targeted massively parallel sequencing of mature lymphoid neoplasms: Assessment of empirical application and diagnostic utility in routine clinical practice. Mod. Pathol. 2021, 34, 904-921. [CrossRef]

221. Pillonel, V.; Juskevicius, D.; Bihl, M.; Stenner, F.; Halter, J.P.; Dirnhofer, S.; Tzankov, A. Routine next generation sequencing of lymphoid malignancies: Clinical utility and challenges from a 3-Year practical experience. Leuk. Lymphoma 2020, 61, 2568-2583. [CrossRef]

222. Morschhauser, F.; Tilly, H.; Chaidos, A.; McKay, P.; Phillips, T.; Assouline, S.; Batlevi, C.L.; Campbell, P.; Ribrag, V.; Damaj, G.L.; et al. Tazemetostat for patients with relapsed or refractory follicular lymphoma: An open-label, single-arm, multicentre, phase 2 trial. Lancet. Oncol. 2020, 21, 1433-1442. [CrossRef] 